\title{
OPEN The effect of prepregnancy body mass index on maternal micronutrient status: a meta-analysis
}

\author{
Yan Yang ${ }^{1,2}$, Zixin Cai ${ }^{1,2}$ \& Jingjing Zhang ${ }^{1 凶}$
}

The relationship between prepregnancy body mass index (BMI) and maternal micronutrient status is inconsistent and has not received sufficient attention. This meta-analysis aimed to evaluate the effect of prepregnancy BMI on micronutrient levels in pregnant women. PubMed, Embase, Web of Science, and the Cochrane Library were searched for articles that contained information on micronutrient levels and prepregnancy BMI. A random-effects model was used to determine the association between prepregnancy BMI and maternal micronutrient status. Sixty-one eligible articles were eventually included, with 83,554 participants. Vitamin B12, folate, vitamin D, iron and ferritin were the main micronutrients evaluated in our meta-analysis. Prepregnancy obesity and overweight may lead to an increased risk of micronutrient deficiency, including vitamin B12, folate and vitamin D deficiency, while prepregnancy obesity or overweight may have no significant association with ferritin deficiency. Additionally, the results of the dose-response analyses demonstrated a possible significant inverse correlation between prepregnancy BMI and levels of micronutrient, except for iron and ferritin. Compared with women with normal weight, women who were overweight or obese prepregnancy have lower micronutrient concentrations and are more likely to exhibit micronutrient deficiency during pregnancy, which is harmful to both mothers and neonates.

Maternal micronutrients play an important role in the health of both mothers and infants ${ }^{1,2}$. For children, maternal micronutrient deficiency can result in perinatal morbidity and mortality and can even lead to chronic complications, such as metabolic syndrome, in adult life ${ }^{1,3}$. For mothers, lean birth can lead to an increased risk of pregnancy complications, including gestational diabetes mellitus and preeclampsia ${ }^{2,4}$.

Maternal obesity, defined as a body mass index (BMI) greater than $30 \mathrm{~kg} / \mathrm{m}^{25}$, is a major public health concern with an increasing prevalence worldwide ${ }^{6}$. Prepregnancy obesity has significant adverse effects on both mothers and offspring ${ }^{7}$. Obese women are more prone to experiencing stillbirth ${ }^{8}$, birth trauma $^{7}$, gestational diabetes mellitus ${ }^{9}$ and preeclampsia ${ }^{10}$ than lean women. Additionally, adverse outcomes (e.g., preterm birth and congenital anomalies) are more common in infants of obese mothers ${ }^{11,12}$.

The micronutrient levels in the obese population are commonly ignored, particularly in pregnant women ${ }^{13}$. However, the consequences of maternal micronutrient deficiency are very harmful. Some of these adverse complications of obesity, such as preterm birth and congenital anomalies, have also been suggested to be related to maternal micronutrient status ${ }^{11,14}$. A report has demonstrated that vitamin D deficiency is common in obese women and increases the risk of food allergies ${ }^{15}$ and adiposity ${ }^{16}$ in offspring. Iron and ferritin may also be related to anthropometric results, while the exact connection is unknown. Increasing evidence has revealed a negative relationship between prepregnancy BMI and maternal micronutrition, mainly including vitamin B12, folate, vitamin $\mathrm{D}$, iron and ferritin ${ }^{17-20}$; other studies have shown the opposite results ${ }^{21-24}$. Overall, the association between maternal micronutrition and obesity is unclear and remains to be studied. Given the inconsistent and ambiguous relationship between micronutrient levels and obesity in pregnant women, we conducted this metaanalysis to determine whether a higher prepregnancy BMI in mothers would lead to low micronutrient levels.

\footnotetext{
${ }^{1}$ National Clinical Research Center for Metabolic Diseases, Metabolic Syndrome Research Center, Key Laboratory of Diabetes Immunology (Central South University), Ministry of Education, and Department of Metabolism and Endocrinology, The Second Xiangya Hospital of Central South University, Changsha 410011, Hunan, China. ${ }^{2}$ These authors contributed equally: Yan Yang and Zixin Cai. ${ }^{\bowtie}$ email: doctorzhangjj@csu.edu.cn
} 


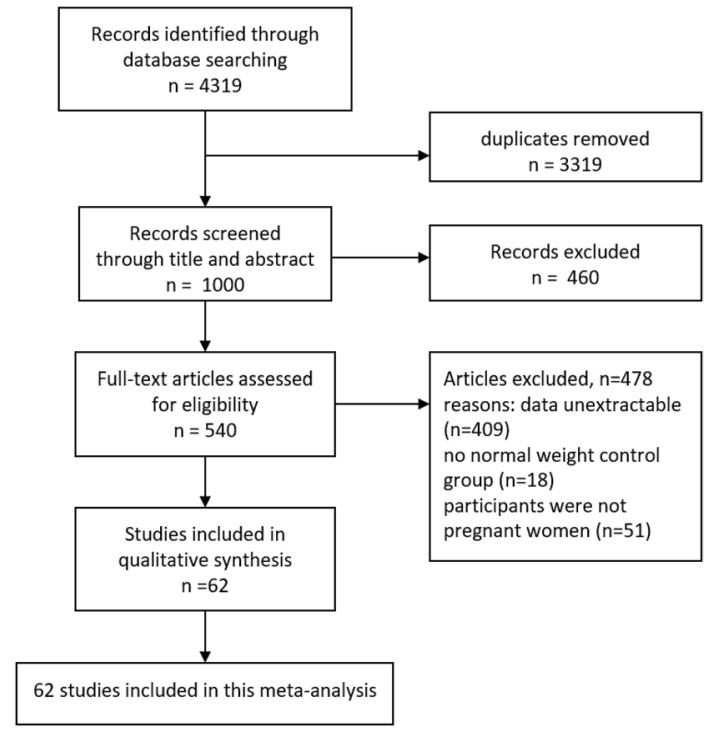

Figure 1. Flow diagram of the study selection process.

\section{Results}

Study characteristics. In total, 4319 studies were initially identified from 4 databases, including PubMed, the Web of Science, Embase and the Cochrane Library (Fig. 1). After removing duplicates, 1000 remaining studies were screened according to the titles and abstracts, and 460 studies were further excluded. Subsequently, 61 studies were selected after removing 487 studies according to the full-text screening. Finally, 61 articles ${ }^{14,22-82}$ were included in our meta-analysis. The main characteristics of the 61 included articles are shown in Table 1. Most of these articles were published between 2010 and 2020. Additionally, the definitions of micronutrient deficiency and methods to measure micronutrient status are listed in Table 2.

Prepregnancy obesity $(B M I \geq 30)$ and micronutrient deficiency. The pooled results from three included studies suggested that prepregnancy obesity $(\mathrm{BMI}>30)$ contributed to an increased risk of vitamin B12 deficiency (OR: 2.13; 95\% CI 1.73, 2.64) (Fig. 2A). Additionally, the overall data from three eligible studies showed that, compared with normal weight, prepregnancy obesity was positively associated with the prevalence of folate deficiency during pregnancy (OR: 1.69; 95\% CI 1.32, 2.16) (Fig. 2B). The results in Fig. 2C from 17 studies demonstrate that prepregnancy obesity may be positively associated with the prevalence of vitamin $\mathrm{D}$ deficiency (OR: 2.03; 95\% CI 1.74, 2.37). However, the data extracted from seven studies revealed that prepregnancy obesity may not be significantly associated with the risk of ferritin deficiency during pregnancy (OR: 1.17; 95\% CI 0.79, 1.73) (Fig. 2D).

Prepregnancy overweight (BMI: 25-29.9) and micronutrient deficiency. The pooled result from four included studies suggested that prepregnancy overweight contributed to an increased risk of vitamin B12 deficiency (OR: 1.25; 95\% CI 1.01, 1.54) (Fig. 3A). The overall data extracted from nine eligible studies showed that, compared with normal weight, prepregnancy overweight was positively associated with the prevalence of folate deficiency during pregnancy (OR: 1.57; 95\% CI 1.05, 2.34) (Fig. 3B). The overall data showed that, compared with normal weight, prepregnancy overweight was positively associated with the prevalence of vitamin $\mathrm{D}$ deficiency during pregnancy (OR: 1.42; 95\% CI 1.25, 1.60) (Fig. 3C). Additionally, prepregnancy overweight may not be significantly associated with the risk of ferritin deficiency (OR: 0.85; 95\% CI 0.63, 1.16) (Fig. 3D).

Prepregnancy BMI and micronutrient level. To further examine the relationship between prepregnancy BMI and vitamin B12, subgroup analysis based on prepregnancy BMI categories was conducted (Fig. 4A). The greatest decreases in vitamin B12 levels were observed in obese women (WMD: $-61.90 \mathrm{pg} / \mathrm{ml} ; 95 \% \mathrm{CI}$ $[-69.47,-54.32]$ ), followed by the overweight group (WMD: $-30.53 \mathrm{pg} / \mathrm{ml}$; 95\% CI [-35.97, -25.08$]$ ). However, prepregnancy underweight was not associated with maternal vitamin B12 levels (WMD: 5.9 pg/ml; $95 \%$ CI $[-5.45,16.03])$.

Second, subgroup analysis of the folate levels based on the prepregnancy BMI categories is shown in Fig. 4B. The greatest decreases in folate levels were observed in overweight women (WMD: $-1.52 \mathrm{ng} / \mathrm{ml}$; $95 \%$ CI $[-1.69$, $-1.36]$ ) and the obese group (WMD: $-1.54 \mathrm{ng} / \mathrm{ml}$; 95\% CI $[-1.63,-1.46]$ ), while underweight prepregnancy may increase maternal folate levels (WMD: $2.05 \mathrm{ng} / \mathrm{ml} ; 95 \%$ CI [1.82, 2.27]).

Third, the association of different prepregnancy BMI categories and vitamin D levels is revealed in Fig. 4C. Maternal vitamin D levels were significantly reduced in prepregnancy obese women (WMD: $-5.66 \mathrm{ng} / \mathrm{ml} ; 95 \%$ 


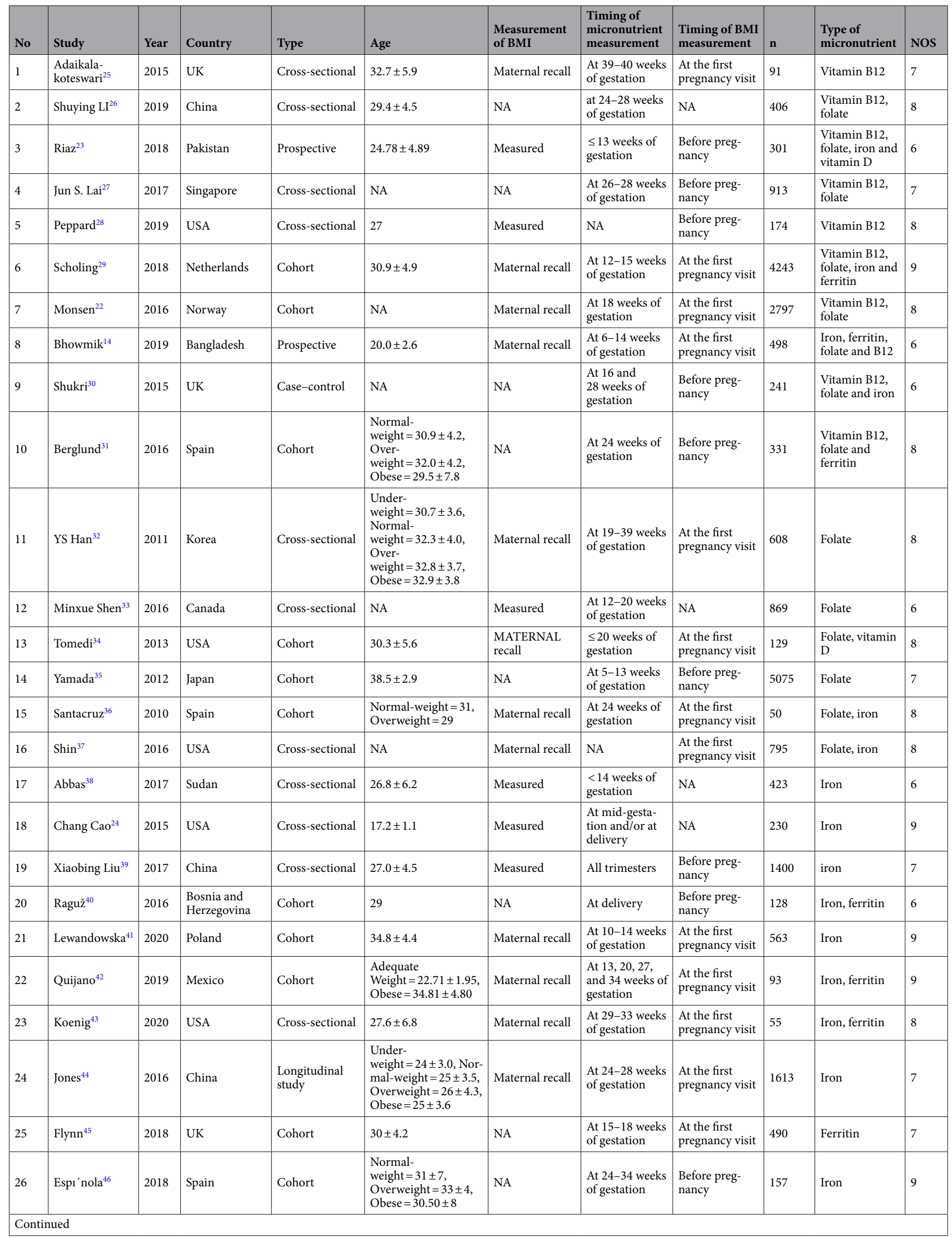




\begin{tabular}{|c|c|c|c|c|c|c|c|c|c|c|c|}
\hline No & Study & Year & Country & Type & Age & $\begin{array}{l}\text { Measurement } \\
\text { of BMI }\end{array}$ & \begin{tabular}{|l|}
$\begin{array}{l}\text { Timing of } \\
\text { micronutrient } \\
\text { measurement }\end{array}$ \\
\end{tabular} & \begin{tabular}{|l|} 
Timing of BMI \\
measurement
\end{tabular} & n & $\begin{array}{l}\text { Type of } \\
\text { micronutrient }\end{array}$ & NOS \\
\hline 27 & Lewicka $^{47}$ & 2019 & Poland & Cross-sectional & $29.5 \pm 4.8$ & Maternal recall & At delivery & $\begin{array}{l}\text { At the first } \\
\text { pregnancy visit }\end{array}$ & 225 & Iron & 8 \\
\hline 28 & Mireku $^{48}$ & 2016 & Benin & Cohort & NA & NA & $\begin{array}{l}\text { At the second } \\
\text { trimester }\end{array}$ & $\begin{array}{l}\text { Before preg- } \\
\text { nancy }\end{array}$ & 636 & Iron & 7 \\
\hline 29 & Bodnar ${ }^{49}$ & 2004 & USA & Cross-sectional & NA & Maternal recall & $\begin{array}{l}\text { At } 24-29 \text { weeks } \\
\text { of gestation }\end{array}$ & $\begin{array}{l}\text { At the first } \\
\text { pregnancy visit }\end{array}$ & 439 & Iron & 6 \\
\hline 30 & Bener $^{50}$ & 2013 & Qatar & Cohort & NA & NA & $\begin{array}{l}\text { Above } 24 \text { weeks } \\
\text { of gestation }\end{array}$ & $\begin{array}{l}\text { Before preg- } \\
\text { nancy }\end{array}$ & 1873 & Iron, vitamin $\mathrm{D}$ & 6 \\
\hline 31 & $\operatorname{cosTA}^{51}$ & 2016 & & Cohort & 31 & NA & $\begin{array}{l}\text { At } 20 \text { weeks of } \\
\text { gestation }\end{array}$ & $\begin{array}{l}\text { Before preg- } \\
\text { nancy }\end{array}$ & & Iron & 6 \\
\hline 32 & Figueiredo ${ }^{52}$ & 2019 & Brazil & Cohort & 26 & Maternal recall & All trimesters & $\begin{array}{l}\text { At the first } \\
\text { pregnancy visit }\end{array}$ & 163 & Vitamin D & 8 \\
\hline 33 & Nobles $^{53}$ & 2015 & USA & Cohort & $18-40$ & & $\begin{array}{l}\text { At } 15.2 \text { weeks } \\
\text { of gestation }\end{array}$ & $\begin{array}{l}\text { Before preg- } \\
\text { nancy }\end{array}$ & 237 & Vitamin D & 9 \\
\hline 34 & Yun $^{54}$ & 2015 & China & Cross-sectional & 26.1 & Maternal recall & NA & $\begin{array}{l}\text { At the first } \\
\text { pregnancy visit }\end{array}$ & 1985 & Vitamin D & 7 \\
\hline 35 & Wang $^{55}$ & 2019 & China & Cross-sectional & \begin{tabular}{|l|} 
Non-overweight \\
and non-obe- \\
sity $=28.8 \pm 3.1$, \\
Overweight and \\
obesity $=28.7 \pm 3.2$
\end{tabular} & Maternal recall & $\begin{array}{l}\text { At } 24-28 \text { weeks } \\
\text { of gestation }\end{array}$ & $\begin{array}{l}\text { At the first } \\
\text { pregnancy visit }\end{array}$ & 140 & Vitamin D & 8 \\
\hline 36 & Chun $^{56}$ & 2017 & Korea & Cross-sectional & 31.6 & NA & $\begin{array}{l}\text { At 3-17 weeks } \\
\text { of gestation }\end{array}$ & $\begin{array}{l}\text { Before preg- } \\
\text { nancy }\end{array}$ & 356 & Vitamin D & 8 \\
\hline 37 & Yan $\operatorname{Tian}^{57}$ & 2016 & USA & Cohort & NA & Maternal recall & $\begin{array}{l}\text { At } 4-29 \text { weeks } \\
\text { of gestation }\end{array}$ & $\begin{array}{l}\text { At the first } \\
\text { pregnancy visit }\end{array}$ & 2558 & Vitamin D & 7 \\
\hline 38 & JM Thorp ${ }^{58}$ & 2012 & USA & Case-control & $\begin{array}{l}\text { Cases }=26.8 \pm 5.5 \\
\text { Controls }=27.3 \pm 5.6\end{array}$ & Measured & $\begin{array}{l}\text { At } 16-21 \text { weeks } \\
\text { of gestation }\end{array}$ & $\begin{array}{l}\text { Before preg- } \\
\text { nancy }\end{array}$ & 265 & Vitamin D & 8 \\
\hline 39 & McAree $^{59}$ & 2014 & UK & Retrospective & NA & Measured & All trimesters & $\begin{array}{l}\text { Before preg- } \\
\text { nancy }\end{array}$ & 346 & Vitamin D & 6 \\
\hline 40 & $\operatorname{Sen}^{60}$ & 2017 & USA & $\begin{array}{l}\text { A secondary } \\
\text { analysis of } \\
\text { randomized } \\
\text { controlled trial }\end{array}$ & $28.4 \pm 5.9$ & Measured & $\begin{array}{l}\text { At } 16 \text { and } \\
28 \text { weeks of } \\
\text { gestation }\end{array}$ & $\begin{array}{l}\text { Before preg- } \\
\text { nancy }\end{array}$ & 234 & Vitamin D & 7 \\
\hline 41 & Xin Zhao ${ }^{61}$ & 2017 & China & Cohort & $27.3 \pm 3.9$ & Maternal recall & $\begin{array}{l}\text { At } 13 \text { weeks of } \\
\text { gestation }\end{array}$ & $\begin{array}{l}\text { At the first } \\
\text { pregnancy visit }\end{array}$ & 13,806 & Vitamin D & 9 \\
\hline 42 & Rodriguez $^{62}$ & 2016 & Spain & Cohort & $30.4 \pm 4.3$ & Maternal recall & $\begin{array}{l}\text { At } 12 \text { weeks of } \\
\text { gestation }\end{array}$ & $\begin{array}{l}\text { At the first } \\
\text { pregnancy visit }\end{array}$ & 2036 & Vitamin D & 9 \\
\hline 43 & Woon $^{63}$ & 2019 & Malaysia & Cohort & $29.9 \pm 4.1$ & Measured & $\begin{array}{l}\text { Above } 28 \text { weeks } \\
\text { of gestation }\end{array}$ & $\begin{array}{l}\text { Before preg- } \\
\text { nancy }\end{array}$ & 535 & Vitamin D & 7 \\
\hline 44 & Tuck $^{64}$ & 2015 & Australia & Cross-sectional & $30.0 \pm 5.4$ & Measured & $\begin{array}{l}\text { At } 12 \text { weeks of } \\
\text { gestation }\end{array}$ & $\begin{array}{l}\text { Before preg- } \\
\text { nancy }\end{array}$ & 1550 & Vitamin D & 7 \\
\hline 45 & Thiele ${ }^{65}$ & 2019 & Portland & Cohort & $30.6 \pm 4.46$ & NA & $\begin{array}{l}\text { Early preg- } \\
\text { nancy }\end{array}$ & $\begin{array}{l}\text { At the first } \\
\text { pregnancy visit }\end{array}$ & 357 & Vitamin D & 8 \\
\hline 46 & Leffelaar ${ }^{66}$ & 2010 & Netherlands & Cohort & $\leq 24,25-34, \geq 35$ & & $\begin{array}{l}\text { Early preg- } \\
\text { nancy }\end{array}$ & $\begin{array}{l}\text { At the first } \\
\text { pregnancy visit }\end{array}$ & 3730 & Vitamin D & 9 \\
\hline 47 & $\mathrm{Choi}^{67}$ & 2015 & Korea & Cohort & 32 & Maternal recall & All trimesters & $\begin{array}{l}\text { At the first } \\
\text { pregnancy visit }\end{array}$ & 220 & Vitamin D & 9 \\
\hline 48 & Eva Morales $^{68}$ & 2014 & Spain & Cohort & $\begin{array}{l}30.2 \pm 4.6,30.4 \pm 4.3 \\
31.0 \pm 4.2\end{array}$ & Maternal recall & $\begin{array}{l}\text { At } 13-15 \text { weeks } \\
\text { of gestation }\end{array}$ & $\begin{array}{l}\text { At the first } \\
\text { pregnancy visit }\end{array}$ & 2358 & Vitamin D & 8 \\
\hline 49 & Santos ${ }^{69}$ & 2018 & Brazil & Cross-sectional & $18-45$ & NA & $\begin{array}{l}\text { Second or third } \\
\text { trimester }\end{array}$ & $\begin{array}{l}\text { At the first } \\
\text { pregnancy visit }\end{array}$ & 190 & Vitamin D & 9 \\
\hline 50 & Merewood ${ }^{70}$ & 2011 & USA & Cross-sectional & $<20,20-<30,30-43$ & Measured & $\begin{array}{l}\text { Second or third } \\
\text { trimester }\end{array}$ & $\begin{array}{l}\text { Before preg- } \\
\text { nancy }\end{array}$ & 459 & Vitamin D & 8 \\
\hline 51 & Karlsson $^{71}$ & 2014 & Sweden & Cross-sectional & \begin{tabular}{|l|} 
Normal- \\
weight $=31.4 \pm 4.0$ \\
Obese $=32.0 \pm 3.2$
\end{tabular} & Maternal recall & First trimester & $\begin{array}{l}\text { At the first } \\
\text { pregnancy visit }\end{array}$ & 105 & Vitamin D & 6 \\
\hline 52 & Burris $^{72}$ & 2014 & USA & Cohort & $32.1 \pm 5.0$ & NA & \begin{tabular}{|l} 
At $16.4-$ \\
36.9 weeks of \\
gestation
\end{tabular} & $\begin{array}{l}\text { Before preg- } \\
\text { nancy }\end{array}$ & 1591 & Vitamin D & 8 \\
\hline 53 & Huang $^{73}$ & 2014 & USA & Cohort & $33.4 \pm 4.2$ & Maternal recall & First trimester & $\begin{array}{l}\text { At the first } \\
\text { pregnancy visit }\end{array}$ & 498 & Vitamin D & 9 \\
\hline 54 & Alonso $^{74}$ & 2011 & Spain & Cross-sectional & $<20,20-29, \geq 30$ & NA & First trimester & $\begin{array}{l}\text { Before preg- } \\
\text { nancy }\end{array}$ & 488 & Vitamin D & 6 \\
\hline 55 & Francis $^{75}$ & 2018 & USA & Cohort & $28.2 \pm 0.5$ & Maternal recall & $\begin{array}{l}\text { At } 10-14 \text { and } \\
15-26 \text { weeks of } \\
\text { gestation }\end{array}$ & $\begin{array}{l}\text { At the first } \\
\text { pregnancy visit }\end{array}$ & 321 & Vitamin D & 8 \\
\hline 56 & Johns $^{76}$ & 2017 & USA & Cohort & $\begin{array}{l}18-24,25-29,30-34 \\
\geq 35\end{array}$ & Measured & $\begin{array}{l}\text { At } 22.9- \\
36.2 \text { weeks of } \\
\text { gestation }\end{array}$ & $\begin{array}{l}\text { Before preg- } \\
\text { nancy }\end{array}$ & 477 & Vitamin D & 6 \\
\hline \multicolumn{12}{|c|}{$\frac{1}{\text { Continued }}$} \\
\hline
\end{tabular}




\begin{tabular}{|c|c|c|c|c|c|c|c|c|c|c|c|}
\hline No & Study & Year & Country & Type & Age & $\begin{array}{l}\text { Measurement } \\
\text { of BMI }\end{array}$ & $\begin{array}{l}\text { Timing of } \\
\text { micronutrient } \\
\text { measurement }\end{array}$ & $\begin{array}{l}\text { Timing of BMI } \\
\text { measurement }\end{array}$ & $\mathbf{n}$ & $\begin{array}{l}\text { Type of } \\
\text { micronutrient }\end{array}$ & NOS \\
\hline 57 & Fernandez ${ }^{77}$ & 2014 & USA & Cohort & $15-24,25-34, \geq 35$ & Maternal recall & $\begin{array}{l}<29 \text { weeks of } \\
\text { gestation }\end{array}$ & $\begin{array}{l}\text { At the first } \\
\text { pregnancy visit }\end{array}$ & 2583 & Vitamin D & 8 \\
\hline 58 & López ${ }^{78}$ & 2013 & Spain & Cross-sectional & $<20,20-29, \geq 30$ & NA & First trimester & $\begin{array}{l}\text { Before preg- } \\
\text { nancy }\end{array}$ & 502 & Vitamin D & 6 \\
\hline 59 & Woolcott ${ }^{79}$ & 2016 & Canada & Case-control & $\begin{array}{l}<25,25-<30 \\
30-<35, \geq 35\end{array}$ & NA & $\begin{array}{l}\text { At } 20-28 \text { weeks } \\
\text { of gestation }\end{array}$ & $\begin{array}{l}\text { Before preg- } \\
\text { nancy }\end{array}$ & 1635 & Vitamin D & 8 \\
\hline 60 & $\operatorname{Jani}^{80}$ & 2020 & Australia & Cohort & $31.06 \pm 5.176$ & Maternal recall & $\begin{array}{l}\text { At } 14 \text { weeks of } \\
\text { gestation }\end{array}$ & $\begin{array}{l}\text { At the first } \\
\text { pregnancy visit }\end{array}$ & 16,528 & Vitamin D & 9 \\
\hline 61 & Daraki $^{81}$ & 2018 & Greece & Cohort & $29.7 \pm 4.9$ & NA & $\begin{array}{l}\text { At } 14 \text { weeks of } \\
\text { gestation }\end{array}$ & $\begin{array}{l}\text { Before preg- } \\
\text { nancy }\end{array}$ & 1226 & Vitamin D & 8 \\
\hline
\end{tabular}

Table 1. Characteristics of the included studies. NA data not available, NOS Newcastle-Ottawa Scale.

\begin{tabular}{|c|c|c|}
\hline Study & Methods of micronutrient measurement & Definition of micronutrient deficiency \\
\hline Musarrat Riaz $(2018)^{23}$ & ELISA/chemiluminescent immunoassay & Vitamin D deficiency $(<30 \mathrm{ng} / \mathrm{ml})$ and low vitamin B12 $(<190 \mathrm{ng} / \mathrm{l})$ \\
\hline Bhowmik $(2019)^{14}$ & ELISA/chemiluminescent immunoassay & $\begin{array}{l}\text { Vitamin D deficiency }(<30 \mathrm{nmol} / \mathrm{l}) \text {, vitamin B12 deficiency }(<200 \mathrm{pg} / \mathrm{ml}) \text {; folate defi- } \\
\text { ciency }(<3 \mathrm{ng} / \mathrm{ml}) \text { and iron deficiency (ferritin }<13 \mathrm{ng} / \mathrm{ml})\end{array}$ \\
\hline Scholing $(2018)^{29}$ & Chemiluminescent immunoassay & $\begin{array}{l}\text { Folate deficiency }(<10 \cdot 0 \mathrm{nmol} / \mathrm{l}) \text {, iron deficiency }(\text { ferritin }<15 \cdot 0 \mu \mathrm{g} / \mathrm{l}) \text { and vitamin B12 } \\
\text { deficiency }(<203 \cdot 3 \mathrm{pg} / \mathrm{ml})\end{array}$ \\
\hline Monsen $(2016)^{22}$ & Microbiological assay & NA \\
\hline Abbas $(2017)^{38}$ & Radioimmunoassay gamma counter and kits & Iron deficiency (ferritin $<15 \mu \mathrm{g} / \mathrm{l}$ ) \\
\hline Chang Cao $(2015)^{24}$ & ELISA & Iron deficiency (ferritin $<12 \mu \mathrm{g} / \mathrm{l}$ ) \\
\hline Jones $(2016)^{76}$ & Chemiluminescent immunoassay & Iron deficiency (ferritin $<15 \mu \mathrm{g} / \mathrm{l}$ ) \\
\hline Koenig $(2020)^{43}$ & $\mathrm{NA}$ & Iron deficiency (ferritin $<12 \mu \mathrm{g} / \mathrm{l}$ ) \\
\hline Flynn $(2018)^{45}$ & ELISA & Iron deficiency (ferritin $<15 \mu \mathrm{g} / \mathrm{l}$ ) \\
\hline Bodnar $(2004)^{49}$ & NA & Iron deficiency (ferritin $<20 \mu \mathrm{g} / \mathrm{l}$ ) \\
\hline Nobles $(2015)^{53}$ & Heartland assays & $25(\mathrm{OH}) \mathrm{D}<20 \mathrm{ng} / \mathrm{ml}$ \\
\hline Tomedi $(2014)^{83}$ & ELISA/chemiluminescent immunoassay & NA \\
\hline Rodriguez $(2016)^{62}$ & BioRAD kit & $25(\mathrm{OH}) \mathrm{D}<20 \mathrm{ng} / \mathrm{ml}$ \\
\hline Lo'pez $(2011)^{78}$ & Chemiluminescent immunoassay & $25(\mathrm{OH}) \mathrm{D}<20 \mathrm{ng} / \mathrm{ml}$ \\
\hline Morales $(2014)^{68}$ & Chemiluminescent immunoassay & $25(\mathrm{OH}) \mathrm{D}<20 \mathrm{ng} / \mathrm{ml}$ \\
\hline Thiele $(2019)^{65}$ & NA & $25(\mathrm{OH}) \mathrm{D}<29 \mathrm{ng} / \mathrm{ml}$ \\
\hline Leffelaar $(2010)^{66}$ & ELISA & $25(\mathrm{OH}) \mathrm{D}<29.9 \mathrm{ng} / \mathrm{ml}$ \\
\hline Daraki $(2018)^{81}$ & Chemiluminescent immunoassay & $25(\mathrm{OH}) \mathrm{D}<37.7 \mathrm{nmol} / \mathrm{l}$ \\
\hline Choi $(2015)^{67}$ & NA & $25(\mathrm{OH}) \mathrm{D}<20 \mathrm{ng} / \mathrm{ml}$ \\
\hline Santos $(2017)^{84}$ & Chemiluminescent immunoassay & $25(\mathrm{OH}) \mathrm{D}<50 \mathrm{nmol} / \mathrm{l}$ \\
\hline Merewood $(2010)^{70}$ & Competitive protein-binding assay & $25(\mathrm{OH}) \mathrm{D}<20 \mathrm{ng} / \mathrm{ml}$ \\
\hline McAree $(2013)^{59}$ & Liquid chromatography coupled to tandem mass spectrometry & $25(\mathrm{OH}) \mathrm{D}<25 \mathrm{nmol} / \mathrm{l}$ \\
\hline Jani $(2020)^{80}$ & NA & $25(\mathrm{OH}) \mathrm{D}<50 \mathrm{nmol} / \mathrm{l}$ \\
\hline TUCK $(2015)^{64}$ & Chemiluminescent immunoassay & $25(\mathrm{OH}) \mathrm{D}<50 \mathrm{nmol} / \mathrm{l}$ \\
\hline Woolcott $(2016)^{79}$ & chemiluminescent immunoassay & $25(\mathrm{OH}) \mathrm{D}<50 \mathrm{nmol} / \mathrm{l}$ \\
\hline
\end{tabular}

Table 2. Characteristics of studies on micronutrient deficiency. NA data not available.

CI $[-5.77,-5.55])$ and the overweight group (WMD: $-1.98 \mathrm{ng} / \mathrm{ml} ; 95 \% \mathrm{CI}[-2.08,-1.89])$, while underweight prepregnancy may slightly increase maternal vitamin D levels (WMD: $0.20 \mathrm{ng} / \mathrm{ml} ; 95 \%$ CI [0.007, 0.32]).

Additionally, the results of the association between different prepregnancy BMI categories and maternal iron were consistent (Fig. 4D). Compared with the normal-weight group, abnormal prepregnancy BMI decreased maternal iron levels (underweight WMD: - $118 \mu \mathrm{g} / \mathrm{L} ; 95 \%$ CI [ - 136.74, - 99.27]; overweight WMD:

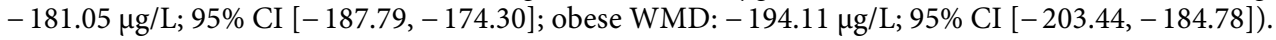

However, as high heterogeneity existed in the above results (Fig. 4), we further conducted subgroup analysis based on methods for BMI measurement, timing of micronutrient measurement and timing of BMI measurement in underweight, overweight and obese women (Supplementary Tables 1-3). Although heterogeneity showed a certain degree of decline or increase, no true cause of heterogeneity can be fully identified, which may result from other information not provided in the included studies.

In contrast to iron, the association between prepregnancy BMI and serum ferritin was inconsistent. Prepregnancy underweight and obesity may be slightly related to the maternal ferritin level (underweight WMD: 
(A)

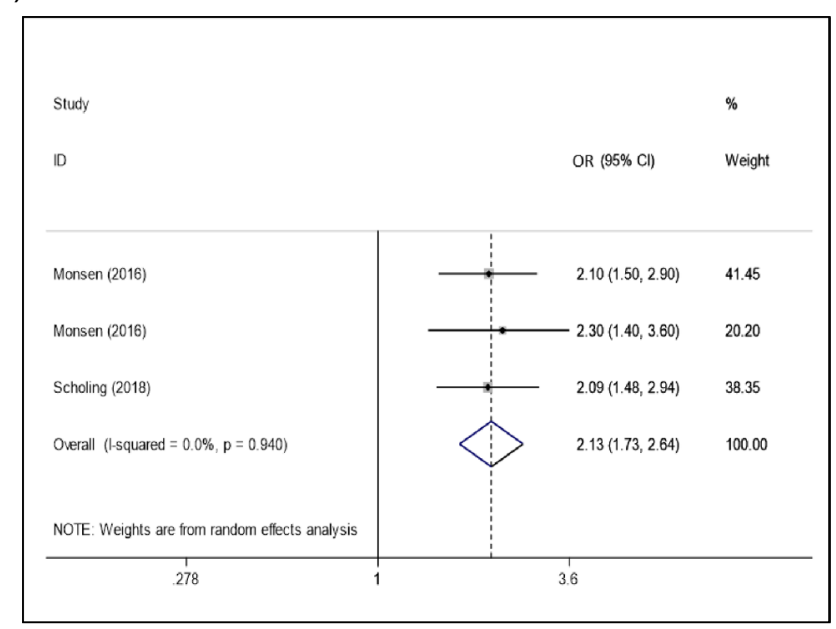

(B)

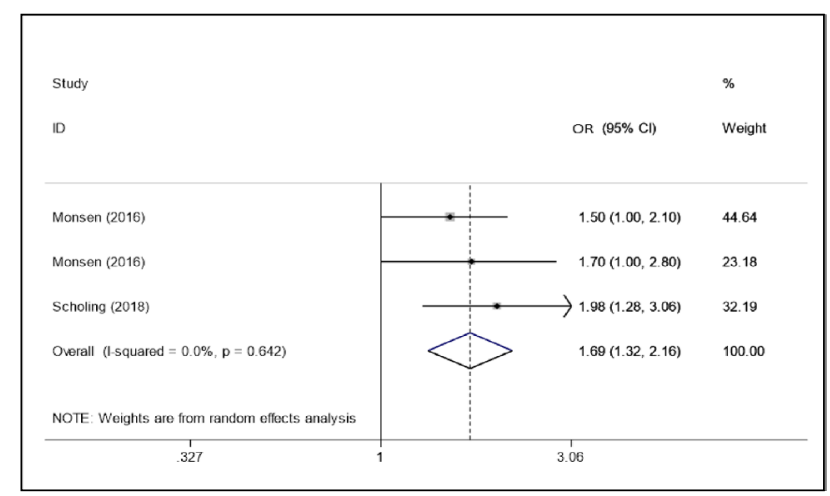

(C)

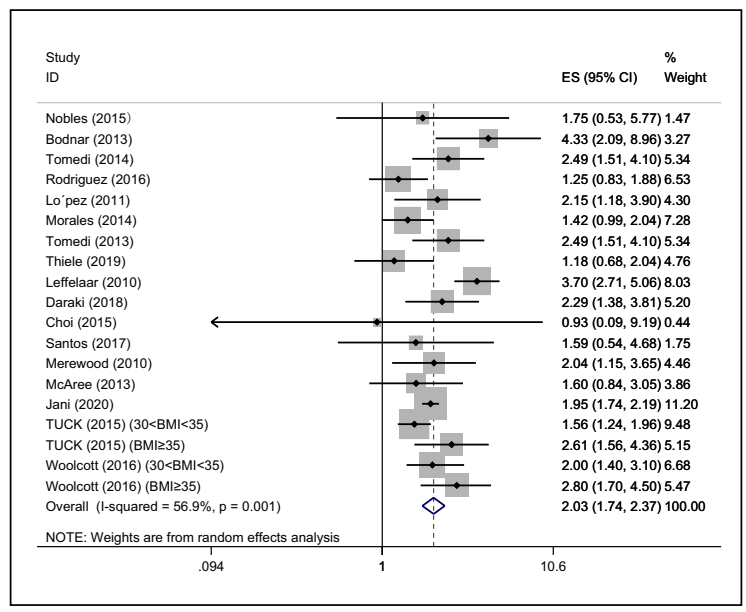

(D)

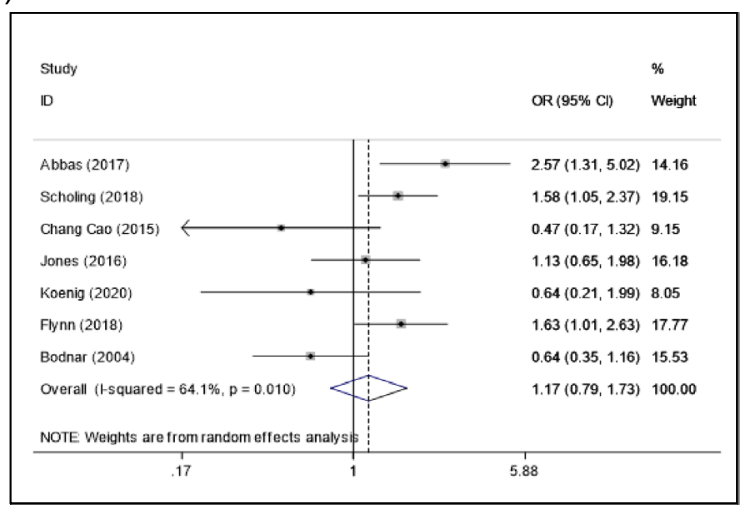

Figure 2. Forest plots of the relationship between prepregnancy obesity and micronutrient deficiency, including that of vitamin B12 (A), folate (B), vitamin D (C), and ferritin (D).

$4.07 \mu \mathrm{g} / \mathrm{l}, 95 \% \mathrm{CI}[2.45,5.66]$; obese WMD: $7.36 \mu \mathrm{g} / \mathrm{l}, 95 \%$ CI $[6.41,8.36])$, while overweight was not associated with ferritin level during pregnancy (WMD: $-0.04 \mathrm{ng} / \mathrm{ml}$; 95\% CI $[-0.68,0.60]$ ) (Fig. 4E).

Dose-response analysis of prepregnancy BMI and micronutrients. Ten studies related to vitamin B12 were included; among them, 24 results were used to examine the dose-response relationship between prepregnancy BMI and vitamin B12. An inverse correlation was observed, as shown in Fig. 5A (coefficient $=-55.12 ; \mathrm{P}=0.001)$.

Thirty-nine data points extracted from 15 studies demonstrated a significant inverse association between prepregnancy $\mathrm{BMI}$ and maternal folate $($ coefficient $=-1.37 ; \mathrm{P}<0.001)$ (Fig. $5 \mathrm{~B})$.

The level of vitamin $\mathrm{D}$ was assessed by $25(\mathrm{OH}) \mathrm{D}$ measurement in the included articles to examine the association between prepregnancy BMI and vitamin D. Twenty-one studies were included in this analysis, and 45 results were extracted from the 21 studies. However, a significant inverse association was found between prepregnancy $\mathrm{BMI}$ and serum vitamin $\mathrm{D}$ (coefficient $=-4.14 ; \mathrm{P}<0.001)$ (Fig. $5 \mathrm{C}$ ).

Eleven studies and 20 subsequent data points revealed a significant inverse relationship between prepregnancy $\mathrm{BMI}$ and serum iron (coefficient $=-165.12 ; \mathrm{P}=0.001)($ Fig. 5D).

Fourteen studies were included, and 30 data points were extracted to examine the association between prepregnancy BMI and serum ferritin. No significant relationship was observed between prepregnancy BMI and serum ferritin (coefficient $=-0.944 ; \mathrm{P}=0.682)$ (Fig. 5E).

Evaluation of publication bias and sensitivity analysis. Funnel plots, Egger's regression test and Begg's rank correlation test were used to analyse publication bias in our meta-analysis. The proportion of statistically significant publication bias tests was not observed for larger meta-analyses, as detected by either Begg's or Egger's test $(\mathrm{P}>0.05)$. Funnel plots also showed symmetric distribution in every analysis (Fig. 6). Overall, no publication bias was found in our meta-analysis. Additionally, sensitivity analysis further demonstrated that our results were stable (Fig. 7). 
(A)

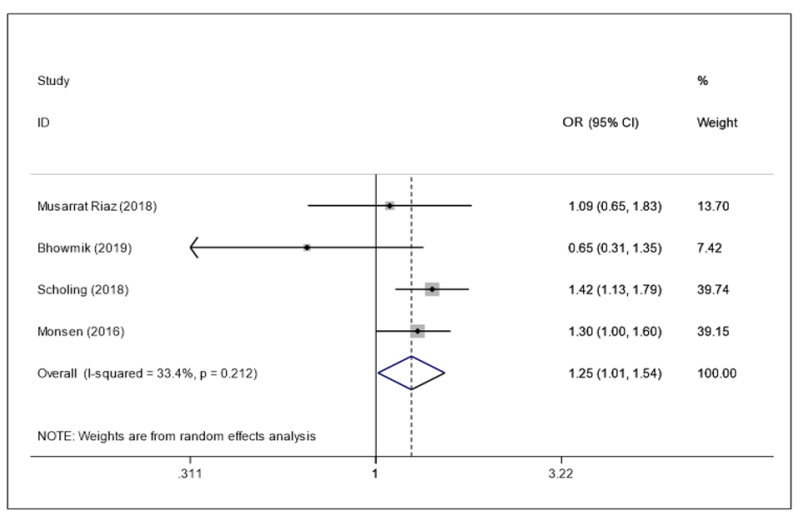

(B)

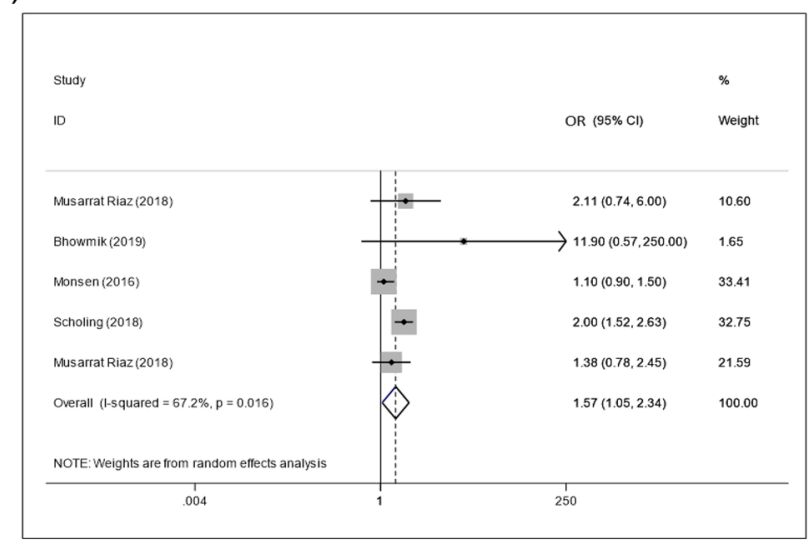

(C)

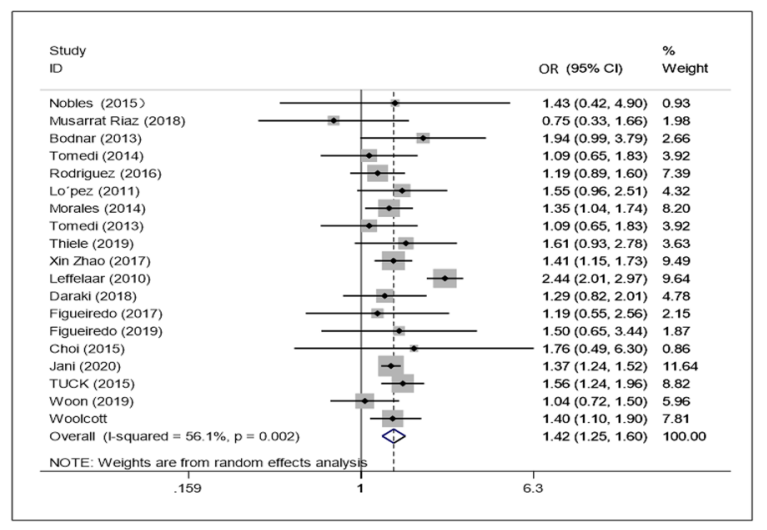

(D)

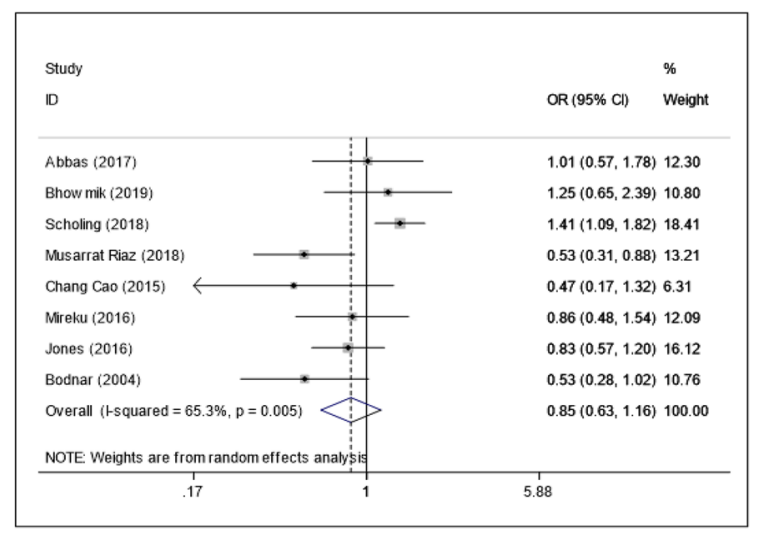

Figure 3. Forest plots of the relationship between prepregnancy overweight and micronutrient deficiency, including that of vitamin B12 (A), folate (B), vitamin D (C), and iron (D).

\section{Discussion}

Micronutrients play an important role in the health of mothers and offspring. The levels of micronutrients in the obese population, particularly in obese pregnant women, are usually neglected. However, recent studies have shown that an inverse relationship may exist between obesity and micronutrient levels ${ }^{17,85}$, while some studies have found the opposite relationship ${ }^{23,24}$. Therefore, we performed the present meta-analysis to resolve this discrepancy. To the best of our knowledge, this systematic review and meta-analysis is the first to assess the relationship between prepregnancy BMI and pregnancy micronutrient levels.

Our study mainly focused on five common micronutrients: vitamin B12, folate, vitamin D, iron and ferritin. Based on our findings from all 62 papers, micronutrient deficiencies, including those of vitamin B12, folate, and vitamin $\mathrm{D}$, were more frequent in obese or overweight pregnant women than in nonobese women (Figs. 2 and 3). Additionally, we found a direct inverse association in pregnant women between prepregnancy BMI and maternal levels of micronutrients, except for ferritin (Figs. 4 and 5).

The aetiology of the inverse relationship between prepregnancy BMI and pregnancy micronutrient levels is unknown. Several factors may partially explain the link between BMI and maternal micronutrition. First, the consumption of a low-quality diet, characterized by less fruit and more calories, including solid fats, alcohol and added sugar ${ }^{37}$, may be an underlying mechanism. Obese people are more likely to consume a low-quality diet, which contributes to a lower intake of micronutrients before and during pregnancy than that of normal-weight women $^{37,86}$.

Second, hepcidin, a marker of chronic inflammation in obesity ${ }^{87}$, may play a significant role in the association between prepregnancy BMI and iron. As an iron-regulating hormone ${ }^{88,89}$, hepcidin is increased in obese women, leading to reduced iron absorption and release ${ }^{87}$. Therefore, prepregnancy BMI may lead to a reduced level of iron in serum by inhibiting iron absorption.

Additionally, the lipid profile, a marker of obesity, is inversely associated with the level of vitamin B12 in T2DM patients ${ }^{90}$. Additionally, blood pressure and metabolic syndrome, complications of obesity, were accompanied by a low vitamin B12 status ${ }^{91,92}$. Thus, vitamin B12 may be reduced because of lipid disorders or complications of obesity.

Our meta-analysis has both practical and research implications. Regarding practical implications, we found that obese prepregnant women have a greater risk of micronutrient deficiency during pregnancy, indicating the importance of micronutrient supplementation and supervision in obese pregnant women. Additionally, we performed dose-response analyses to demonstrate the relationship between prepregnancy BMI and maternal 

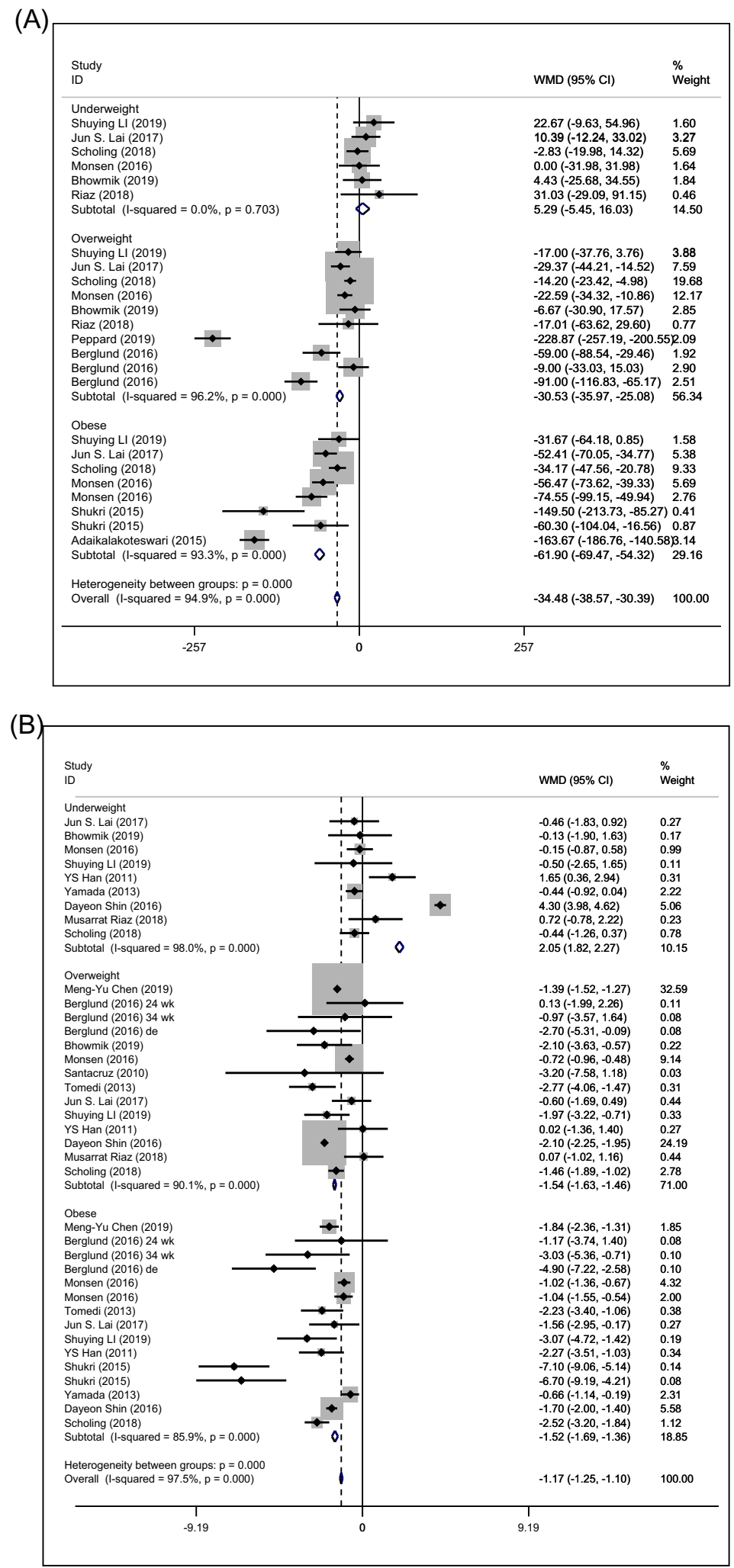

Figure 4. Forest plots between prepregnancy BMI and micronutrient deficiency, including vitamin B12 (A), folate (B), vitamin D (C), iron (D) and ferritin (E). Subgroup analysis of combined weighted mean differences with $95 \%$ confidence intervals was stratified by the prepregnancy BMI.

micronutrient levels, including those of vitamin B12, folate, vitamin D, iron and ferritin. Finally, the relationship 
(C)

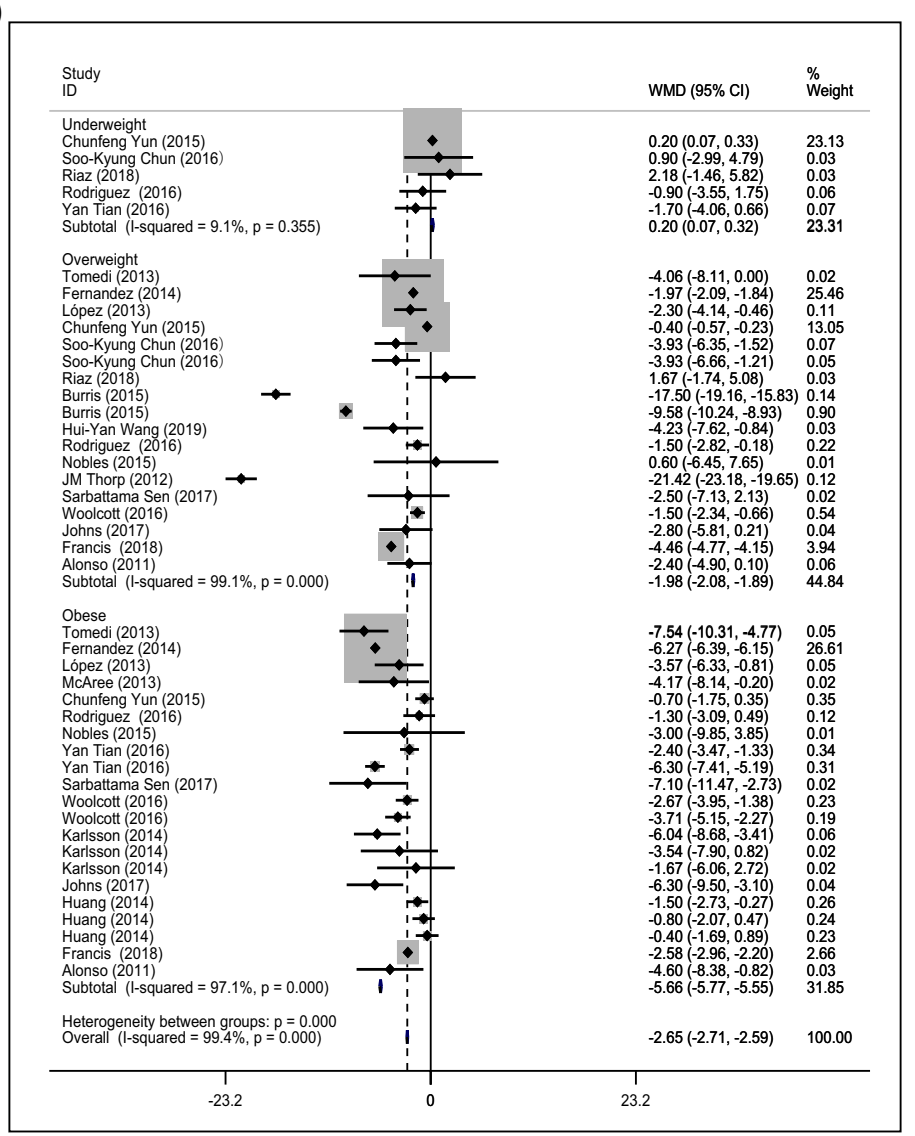

(D)

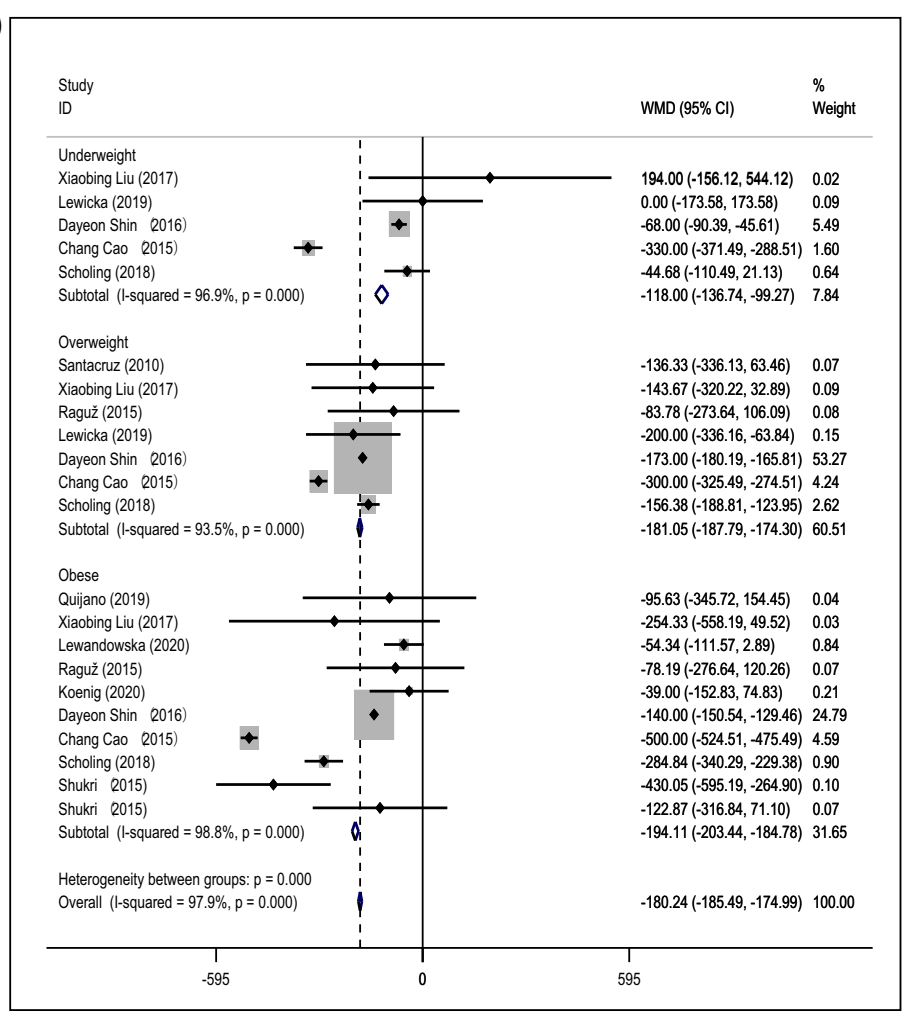

Figure 4. (continued) 
(E)

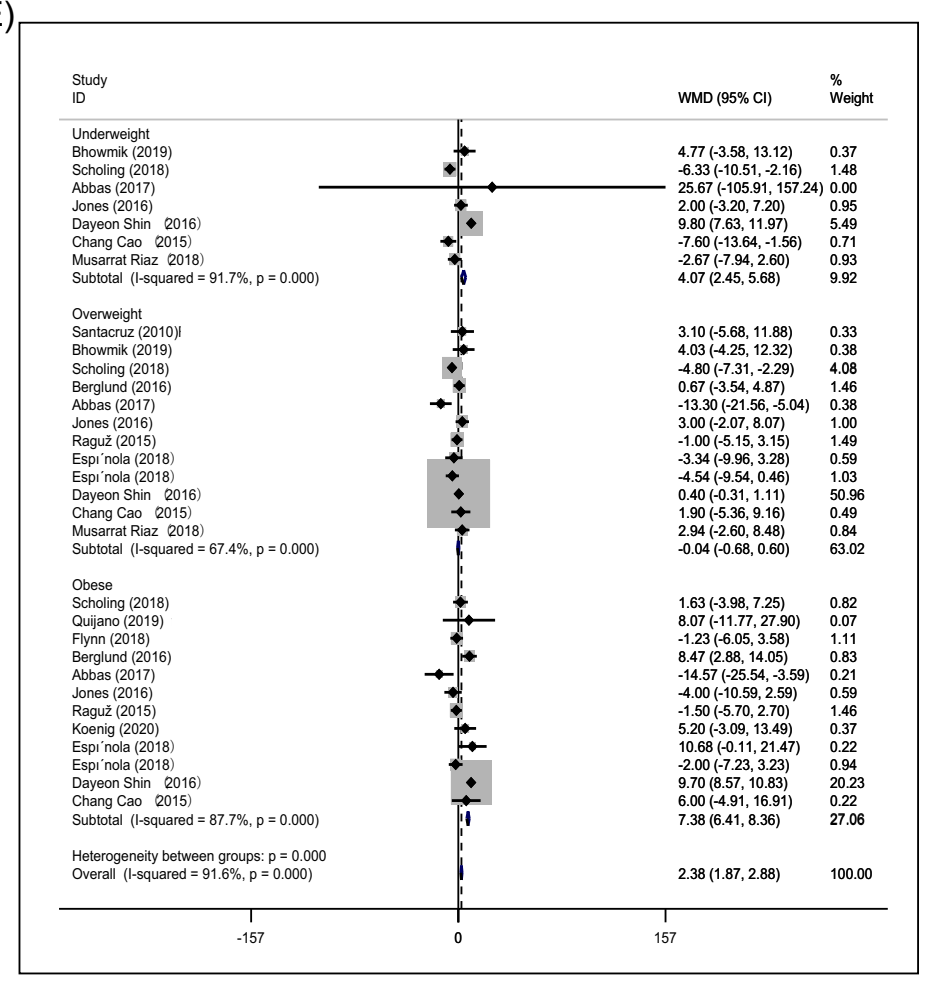

Figure 4. (continued)

between prepregnancy obesity and micronutrients was systematically summarized in our study. Regarding research implications, identifying the underlying mechanisms of the effects of prepregnancy BMI on micronutrient deficiency may be an important direction of future research in this field to keep mothers and infants safe.

Although our study partially revealed the effects of obesity on pregnancy micronutrient levels, these levels were only measured during pregnancy and not before pregnancy in the included articles. Hence, future studies should include more details, such as prepregnancy micronutrient levels, to fully prove causality between BMI and pregnancy micronutrient levels. Additionally, high heterogeneity existed in our results. Information on the method and timing of BMI measurements, period of micronutrient measurement (Table 1) and definition of micronutrient deficiency (Table 2) were inconsistent, likely contributing to the high heterogeneity of our results. Furthermore, because some prepregnancy BMIs were obtained from maternal recall, which is not as accurate as the measured BMIs (Table 1), recall bias may exist in our analysis, and future clinical studies should focus more on the use of uniformly measured prepregnancy BMIs to avoid this bias. Moreover, the definition of micronutrient deficiency was not uniform in the different included papers (Table 2); for example, the different standards of deficiency are also a limitation, and more well-designed clinical studies are required. Additionally, as we did not add other iron biomarkers, including transferrin receptor and transferrin saturation, future meta-analyses to analyse the association between prepregnancy BMI and other iron levels are needed.

Finally, because micronutrient concentrations are often measured from plasma or serum, rather than whole blood, plasma volume changes during pregnancy can influence the concentrations of these micronutrients ${ }^{93,94}$. Therefore, new micronutrient cut-offs may be needed in future studies to avoid the possible effect of haemodilution in pregnant women. However, we focused on the relationship between prepregnancy BMI and maternal micronutrient levels, and the target population was pregnant women; thus, the effect of haemodilution may not affect our conclusion.

In conclusion, our study revealed that prepregnancy obesity or overweight may lead to an increased risk of micronutrient deficiency during pregnancy. Therefore, we emphasize that clinical micronutrient screening is necessary for overweight or obese pregnant women.

\section{Methods}

Search strategy. This meta-analysis was rigorously reported according to the Preferred Reporting Items for Systematic Reviews and Meta-Analyses (PRISMA) statement, as previously described ${ }^{95}$. This protocol analysis was registered on the PROSPERO website (protocol number: CRD42020188646). In this study, four electronic databases, PubMed, Embase, Cochrane Library and Web of Science, were searched for articles relevant to micronutrients and obesity through May 2020. The search terms were "BMI", "obesity", "overweight" and "body mass index" combined with "micronutrient", "vitamin B12", "folate", "vitamin D", "iron", and "ferritin". Additionally, we evaluated the references of the articles and reviews on micronutrients to identify studies that were not indexed in the databases but would be eligible for inclusion in this meta-analysis. 
A

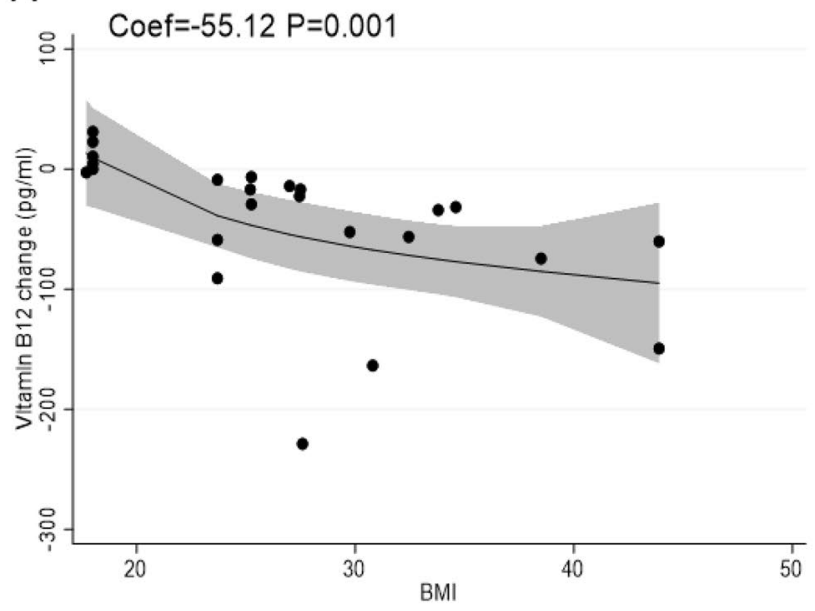

C

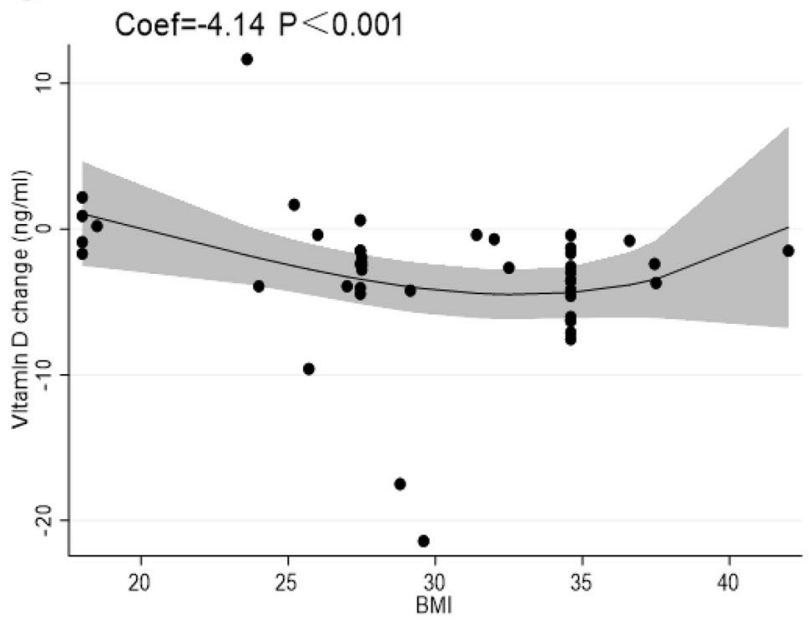

$E$

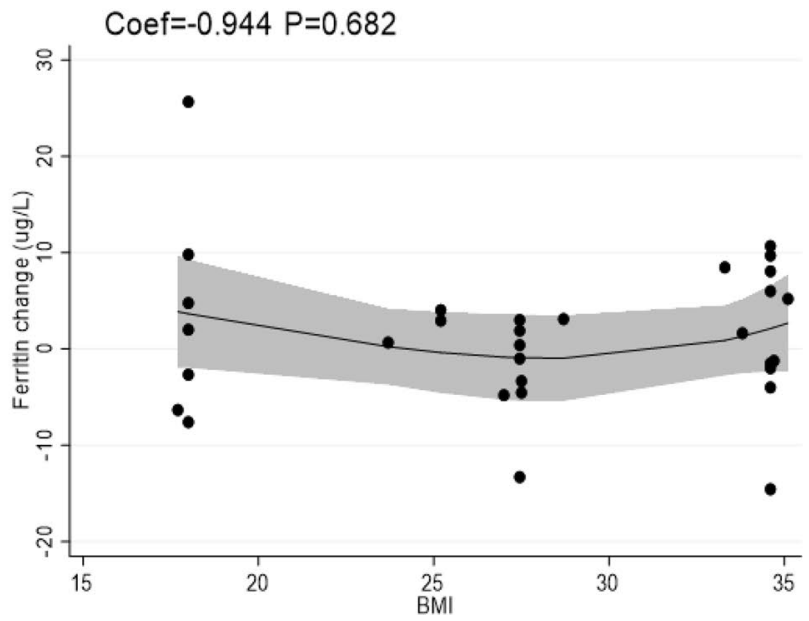

B

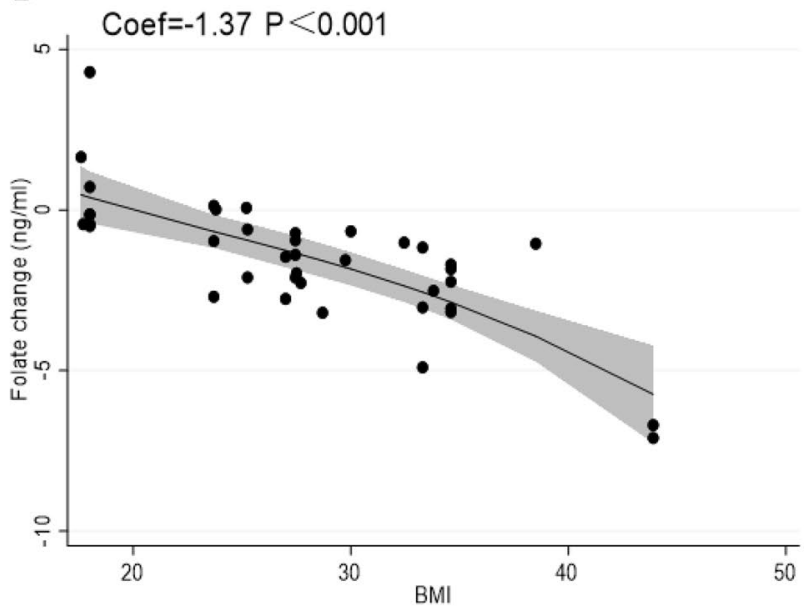

D

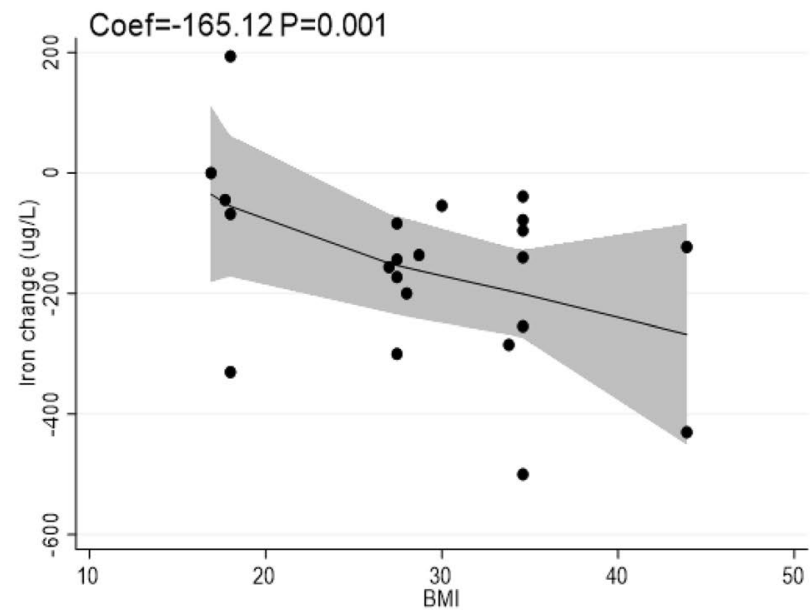

Figure 5. Nonlinear dose responses between prepregnancy BMI and micronutrient levels, including those of vitamin B12 (A), folate (B), vitamin D (C), iron (D) and ferritin (E).

Selection criteria. Two reviewers (YY and ZC) reviewed all the included studies and determined study eligibility. Disagreements were settled by consensus or the help of a third reviewer (JZ). All the articles included in this meta-analysis met the following criteria: (1) studies with information on obesity and micronutrients; (2) 
A

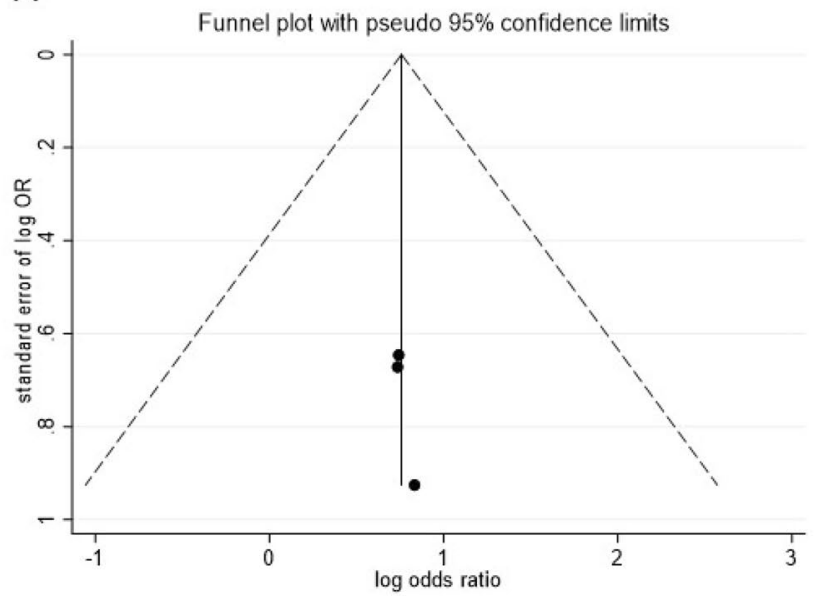

C

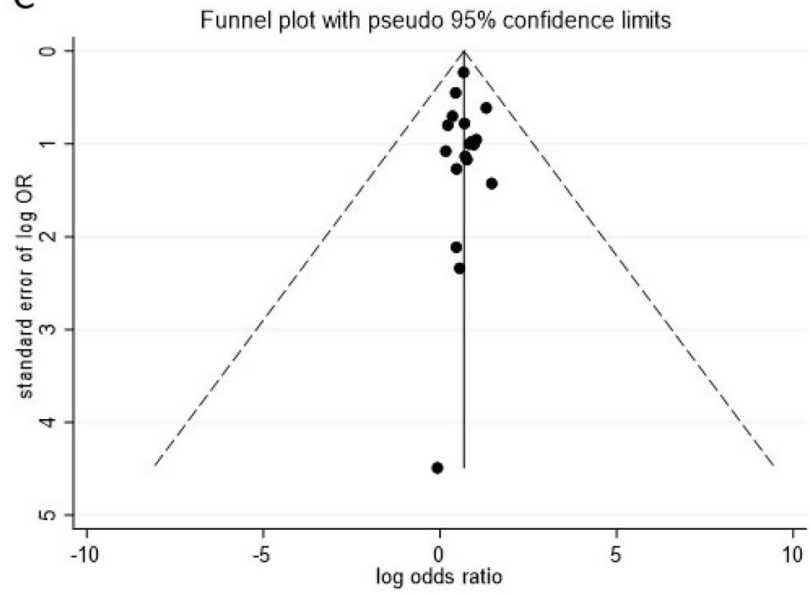

B

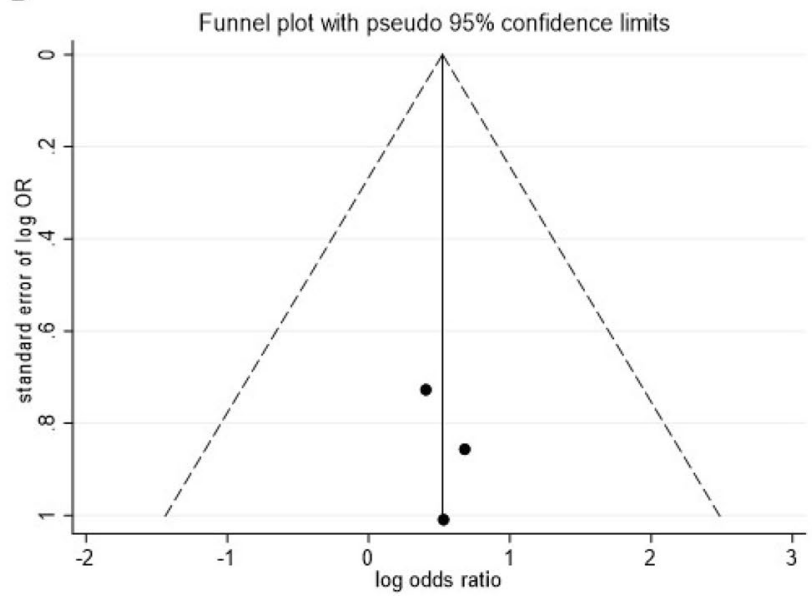

D

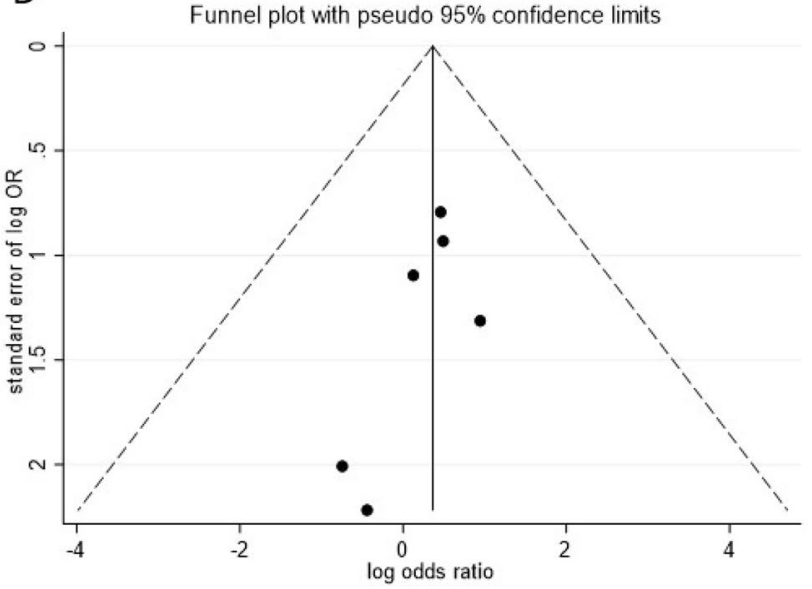

Figure 6. Funnel plots between prepregnancy obesity and micronutrient deficiency, including those of vitamin B12 (A), folate (B), vitamin D (C), and iron (D).

studies published in English; and (3) studies in which the micronutrients were limited to vitamin B12, folate, vitamin D, iron and ferritin. Additionally, articles were excluded if they met the following criteria: (1) articles that involved individuals who had undergone bariatric surgery; (2) articles that were literature reviews, communications or editorials; (3) studies with methodological weaknesses, such as inference data for the population from a nonrepresentative sample and studies that evaluated the relationship between prepregnancy BMI and nutritional status but did not explain the methodology or parameters used to evaluate these events; (4) studies in which data reported only in meeting abstracts would have been included if the abstract contained sufficient information for assessment; and (5) studies that did not have available information or usable data for this metaanalysis.

Data extraction. All relevant articles were entered in EndNote X8 software and reviewed independently by two authors (YY and ZC). Discrepancies between authors were settled with the help of a third reviewer (JZ). The following information was extracted from the final studies: name of the first author, year of publication, country, sample size, study design, prepregnancy BMI, type of micronutrient, level of micronutrient, and odds ratio (OR) and $95 \%$ confidence interval (CI) of the micronutrient deficiency. All the extracted data were then imported into Excel software.

Quality assessment of studies. The quality of the included studies was assessed using the NewcastleOttawa Scale (NOS) ${ }^{96}$. The measures on this scale comprise three items: the selection of participants, comparability of cases and controls, and ascertainment of outcomes. The scale has a minimum score of 0 and a maximum score of 9 . Studies scoring at least 7 (corresponding to $78 \%$ of the maximum score) were regarded as having a low risk of bias ('good' quality), those scoring 4-6 were deemed to have a modest risk of bias ('fair' quality), and those scoring $<3$ were considered to have a substantial risk of bias ('poor' quality) ${ }^{97}$. We assessed the quality of all the relevant studies in accordance with the type of study, sample size, participant selection, representativeness of the 
A
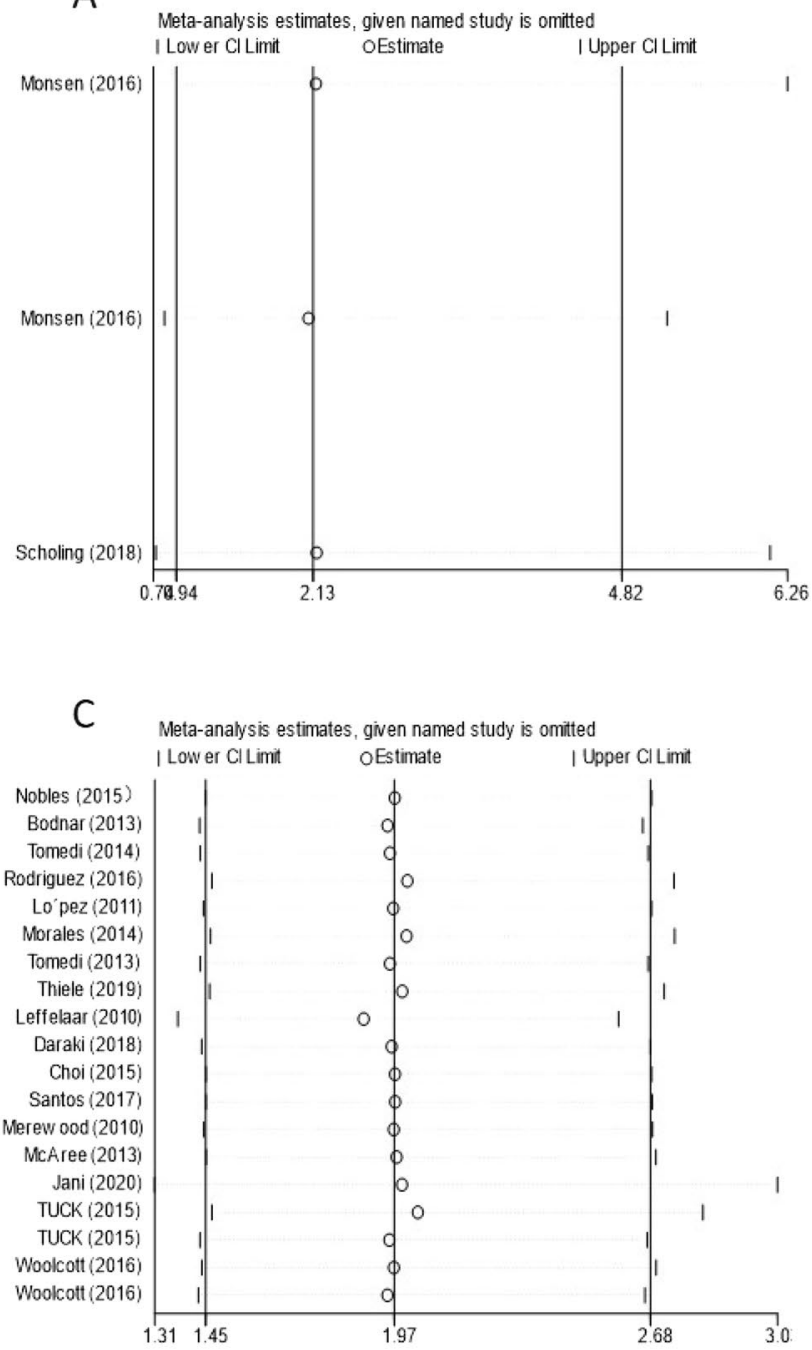

B

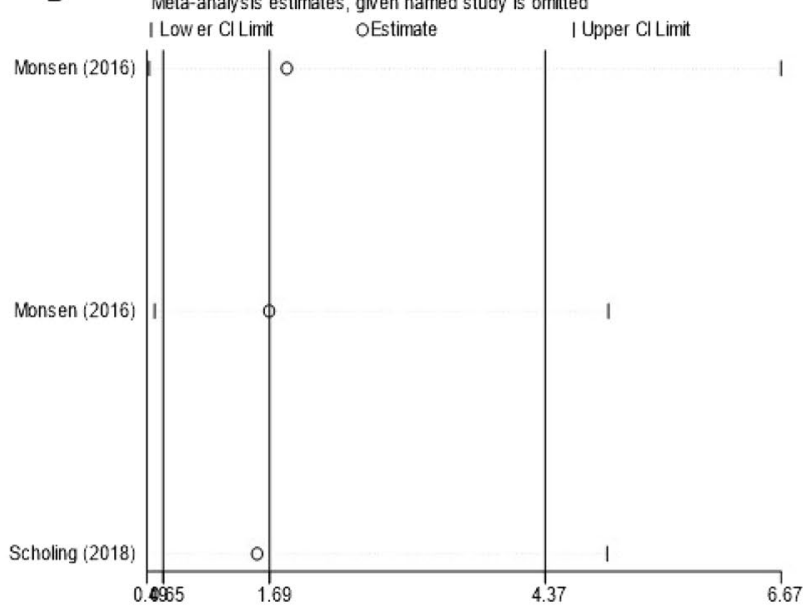

Figure 7. Sensitivity analysis between prepregnancy obesity and micronutrient deficiency, including that of vitamin B12 (A), folate (B), vitamin D (C), and iron (D).

sample (case or exposure group), adequacy of follow-up, comparability (exposed-unexposed or case-control), and method of ascertainment for cases and controls. Finally, high-quality studies were included in the analyses. Two investigators (YY and ZC) independently performed the quality assessment. Any disagreements were settled with the help of a third reviewer (JZ) when necessary.

Definition. Based on all the included studies, we classified BMI based on the World Health Organization $(\mathrm{WHO})$ standards (underweight: $\mathrm{BMI} \leq 18.5$; normal weight: BMI 18.5-24.9; overweight: BMI 25-29.9; obesity: BMI $\geq 30$ ). Doses (mean of BMI category) were defined as follows according to the data from the Scott-Pillai study ${ }^{98}$ : BMI 18.5-24.9=21.7; BMI 25-29.9=27.45; BMI 30-34.9=32.45; BMI 35-39.9=37.45; $\mathrm{BMI} \leq 20=18.5 ; \mathrm{BMI}<25=21 ; \mathrm{BMI} \geq 25=30 ; \mathrm{BMI}<30=23.7 ; \mathrm{BMI} \geq 30=34.6 ; \mathrm{BMI} \geq 35=38.5 ; \mathrm{BMI} \leq 18.5=18$ and $\mathrm{BMI} \geq 40=41$. Additionally, ferritin is an iron-storing protein, with serum ferritin regarded as a measurement of total body iron stores ${ }^{99}$. Furthermore, independent of iron status, serum ferritin is also increased by inflammation in the body because ferritin is an acute-phase protein ${ }^{99}$. To evaluate the potential dose-response relationship between $\mathrm{BMI}$ and micronutrient levels, a dose-response meta-analysis was conducted to compute the trend from the correlated values of BMI across various micronutrient levels.

Statistical analysis. We gathered data on the prevalence of micronutrient deficiencies in various groups classified according to prepregnancy BMI. We gathered the results worldwide from different ethnicities and regions. Therefore, we used the random-effects model to obtain the meta-analysis results. Odds ratios (ORs) and CIs were used as summary measurements for the meta-analysis, and the results are presented as forest plots. Continuous variable effect size was defined as weighted mean differences (WMDs) and 95\% CIs calculated for changes in micronutrient concentrations. Pooled WMDs with 95\% CIs were calculated using the mean and standard deviation from each study by Stata 5 software. The correlation coefficient was used as another summary 
measure for the outcome studies, presented as dose response analyses. All statistical analyses were performed using Stata software (Version 13.0). The heterogeneity among all the studies was assessed by $\mathrm{I}^{2}$ statistics. The bias of the study was analysed using funnel plots. Sensitivity analysis was performed by leaving out each study one by one to evaluate the credibility of the pooled results.

Received: 23 June 2020; Accepted: 9 August 2021

Published online: 13 September 2021

\section{References}

1. Marsal, K. Intrauterine growth restriction. Curr. Opin. Obstet. Gynecol. 14, 127-135. https://doi.org/10.1097/00001703-20020 4000-00005 (2002).

2. Bodnar, L. M. et al. Maternal vitamin D status and the risk of mild and severe preeclampsia. Epidemiology 25, 207-214. https:// doi.org/10.1097/ede.0000000000000039 (2014).

3. Barker, D. J. \& Clark, P. M. Fetal undernutrition and disease in later life. Rev. Reprod. 2, 105-112. https://doi.org/10.1530/ror.0. 0020105 (1997).

4. Lu, M., Xu, Y., Lv, L. \& Zhang, M. Association between vitamin D status and the risk of gestational diabetes mellitus: A metaanalysis. Arch. Gynecol. Obstet. 293, 959-966. https://doi.org/10.1007/s00404-016-4010-4 (2016).

5. Heslehurst, N., Rankin, J., Wilkinson, J. R. \& Summerbell, C. D. A nationally representative study of maternal obesity in England, UK: Trends in incidence and demographic inequalities in 619,323 births, 1989-2007. Int. J. Obes. 2005(34), 420-428. https://doi. org/10.1038/ijo.2009.250 (2010).

6. Swinburn, B. A. et al. The global obesity pandemic: Shaped by global drivers and local environments. Lancet (London, England) 378, 804-814. https://doi.org/10.1016/s0140-6736(11)60813-1 (2011).

7. Cedergren, M. I. Maternal morbid obesity and the risk of adverse pregnancy outcome. Obstet. Gynecol. 103, 219-224. https://doi. org/10.1097/01.Aog.0000107291.46159.00 (2004).

8. Cnattingius, S., Bergstrom, R., Lipworth, L. \& Kramer, M. S. Prepregnancy weight and the risk of adverse pregnancy outcomes. N. Engl. J. Med. 338, 147-152. https://doi.org/10.1056/nejm199801153380302 (1998).

9. Chu, S. Y. et al. Maternal obesity and risk of gestational diabetes mellitus. Diabetes Care 30, 2070-2076. https://doi.org/10.2337/ dc06-2559a (2007).

10. Hauger, M. S., Gibbons, L., Vik, T. \& Belizan, J. M. Prepregnancy weight status and the risk of adverse pregnancy outcome. Acta Obstet. Gynecol. Scand. 87, 953-959. https://doi.org/10.1080/00016340802303349 (2008).

11. Catalano, P. M. \& Ehrenberg, H. M. The short- and long-term implications of maternal obesity on the mother and her offspring. BJOG Int. J. Obstetr. Gynaecol. 113, 1126-1133. https://doi.org/10.1111/j.1471-0528.2006.00989.x (2006).

12. Stothard, K. J., Tennant, P. W., Bell, R. \& Rankin, J. Maternal overweight and obesity and the risk of congenital anomalies: A systematic review and meta-analysis. JAMA 301, 636-650. https://doi.org/10.1001/jama.2009.113 (2009).

13. Li, Y., Wang, C., Zhu, K., Feng, R. N. \& Sun, C. H. Effects of multivitamin and mineral supplementation on adiposity, energy expenditure and lipid profiles in obese Chinese women. Int. J. Obes. 2005(34), 1070-1077. https://doi.org/10.1038/ijo.2010.14 (2010).

14. Bhowmik, B. et al. Maternal BMI and nutritional status in early pregnancy and its impact on neonatal outcomes at birth in Bangladesh. BMC Pregnancy Childbirth 19, 413. https://doi.org/10.1186/s12884-019-2571-5 (2019).

15. Liu, X. et al. Longitudinal trajectory of vitamin D status from birth to early childhood in the development of food sensitization. Pediatr. Res. 74, 321-326. https://doi.org/10.1038/pr.2013.110 (2013).

16. Crozier, S. R. et al. Maternal vitamin D status in pregnancy is associated with adiposity in the offspring: Findings from the Southampton Women's Survey. Am. J. Clin. Nutr. 96, 57-63. https://doi.org/10.3945/ajcn.112.037473 (2012).

17. Sukumar, N. et al. Vitamin B12 status among pregnant women in the UK and its association with obesity and gestational diabetes. Nutrients https://doi.org/10.3390/nu8120768 (2016).

18. O’Malley, E. G. et al. Folate and vitamin B12 levels in early pregnancy and maternal obesity. Eur. J. Obstet. Gynecol. Reprod. Biol. 231, 80-84. https://doi.org/10.1016/j.ejogrb.2018.10.001 (2018).

19. Dao, M. C., Sen, S., Iyer, C., Klebenov, D. \& Meydani, S. N. Obesity during pregnancy and fetal iron status: Is Hepcidin the link?. J. Perinatol. 33, 177-181. https://doi.org/10.1038/jp.2012.81 (2013).

20. Chrisostomo, K. R. et al. The prevalence and clinical associations of hypovitaminosis D in pregnant women from Brazil. Int. J. Gynaecol. Obstetr. 143, 66-70. https://doi.org/10.1002/ijgo.12575 (2018).

21. Karabulut, A., Sevket, O. \& Acun, A. Iron, folate and vitamin B12 levels in first trimester pregnancies in the Southwest region of Turkey. J. Turk. German Gynecol. Assoc. 12, 153-156. https://doi.org/10.5152/jtgga.2011.36 (2011).

22. Bjørke-Monsen, A. L. et al. Impact of pre-pregnancy BMI on B vitamin and inflammatory status in early pregnancy: An observational cohort study. Nutrients https://doi.org/10.3390/nu8120776 (2016).

23. Riaz, M. et al. Maternal nutrition during early pregnancy and cardiometabolic status of neonates at birth. J. Diabetes Res. 2018 , 7382946. https://doi.org/10.1155/2018/7382946 (2018).

24. Cao, C. et al. Prepregnancy body mass index and gestational weight gain have no negative impact on maternal or neonatal iron status. Reproduct. Sci. (Thousand Oaks, Calif.) 23, 613-622. https://doi.org/10.1177/1933719115607976 (2016).

25. Adaikalakoteswari, A. et al. Low maternal vitamin B12 status is associated with lower cord blood HDL cholesterol in white Caucasians living in the UK. Nutrients 7, 2401-2414. https://doi.org/10.3390/nu7042401 (2015).

26. Li, S. et al. Joint effects of folate and vitamin B(12) imbalance with maternal characteristics on gestational diabetes mellitus. J. Diabetes 11, 744-751. https://doi.org/10.1111/1753-0407.12899 (2019).

27. Lai, J. S. et al. High folate and low vitamin B12 status during pregnancy is associated with gestational diabetes mellitus. Clin. Nutr. 37, 940-947. https://doi.org/10.1016/j.clnu.2017.03.022 (2018).

28. Peppard, L., Oh, K. M., Gallo, S. \& Milligan, R. Risk of depression in pregnant women with low-normal serum Vitamin B12. Res. Nurs. Health 42, 264-272. https://doi.org/10.1002/nur.21951 (2019).

29. Scholing, J. M., Olthof, M. R., Jonker, F. A. \& Vrijkotte, T. G. Association between pre-pregnancy weight status and maternal micronutrient status in early pregnancy. Public Health Nutr. 21, 2046-2055. https://doi.org/10.1017/s1368980018000459 (2018).

30. Mohd-Shukri, N. A. et al. Health behaviours during pregnancy in women with very severe obesity. Nutrients 7, 8431-8443. https:// doi.org/10.3390/nu7105403 (2015).

31. Berglund, S. K. et al. Maternal, fetal and perinatal alterations associated with obesity, overweight and gestational diabetes: An observational cohort study (PREOBE). BMC Public Health 16, 207. https://doi.org/10.1186/s12889-016-2809-3 (2016).

32. Han, Y. S., Ha, E. H., Park, H. S., Kim, Y. J. \& Lee, S. S. Relationships between pregnancy outcomes, biochemical markers and pre-pregnancy body mass index. Int. J. Obes. (Lond.) 35, 570-577. https://doi.org/10.1038/ijo.2010.162 (2011). 
33. Shen, M. et al. Serum and red-blood-cell folate demonstrate differential associations with BMI in pregnant women. Public Health Nutr. 19, 2572-2579. https://doi.org/10.1017/s1368980016000756 (2016).

34. Tomedi, L. E., Simhan, H. N. \& Bodnar, L. M. Early-pregnancy maternal vitamin D status and maternal hyperglycaemia. Diabetic Med. 30, 1033-1039. https://doi.org/10.1111/dme.12229 (2013).

35. Yamada, T. et al. First-trimester serum folate levels and subsequent risk of abortion and preterm birth among Japanese women with singleton pregnancies. Arch. Gynecol. Obstet. 287, 9-14. https://doi.org/10.1007/s00404-012-2501-5 (2013).

36. Santacruz, A. et al. Gut microbiota composition is associated with body weight, weight gain and biochemical parameters in pregnant women. Br. J. Nutr. 104, 83-92. https://doi.org/10.1017/s0007114510000176 (2010).

37. Shin, D., Lee, K. W. \& Song, W. O. Pre-pregnancy weight status is associated with diet quality and nutritional biomarkers during pregnancy. Nutrients 8, 162. https://doi.org/10.3390/nu8030162 (2016).

38. Abbas, W., Adam, I., Rayis, D. A., Hassan, N. G. \& Lutfi, M. F. Higher rate of iron deficiency in obese pregnant sudanese women. Open Access Macedonian J. Med. Sci. 5, 285-289. https://doi.org/10.3889/oamjms.2017.059 (2017).

39. Liu, X. et al. Reference values of 14 serum trace elements for pregnant Chinese women: A cross-sectional study in the China Nutrition and Health Survey 2010-2012. Nutrients https://doi.org/10.3390/nu9030309 (2017).

40. Raguž, M. J. \& Brzica, J. Does body mass index in pregnant women affect laboratory parameters in the newborn?. AJP Rep. 6, e155-159. https://doi.org/10.1055/s-0036-1582135 (2016).

41. Lewandowska, M., Więckowska, B., Sajdak, S. \& Lubiński, J. First trimester microelements and their relationships with pregnancy outcomes and complications. Nutrients https://doi.org/10.3390/nu12041108 (2020).

42. Flores-Quijano, M. E. et al. Obesity is associated with changes in iron nutrition status and its homeostatic regulation in pregnancy. Nutrients https://doi.org/10.3390/nu11030693 (2019).

43. Koenig, M. D. et al. Prepregnancy obesity is not associated with iron utilization during the third trimester. J. Nutr. 150, 1397-1404. https://doi.org/10.1093/jn/nxaa065 (2020).

44. Jones, A. D. et al. Maternal obesity during pregnancy is negatively associated with maternal and neonatal iron status. Eur. J. Clin. Nutr. 70, 918-924. https://doi.org/10.1038/ejcn.2015.229 (2016).

45. Flynn, A. C. et al. Relationships between maternal obesity and maternal and neonatal iron status. Nutrients https://doi.org/10. 3390/nu10081000 (2018).

46. Torres-Espínola, F. J. et al. Visual evoked potentials in offspring born to mothers with overweight, obesity and gestational diabetes. PLoS ONE 13, e0203754. https://doi.org/10.1371/journal.pone.0203754 (2018).

47. Lewicka, I. et al. Relationship between pre-pregnancy body mass index and mineral concentrations in serum and amniotic fluid in pregnant women during labor. J. Trace Elements Med. Biol. Organ Soc. Miner. Trace Elements (GMS) 52, 136-142. https://doi. org/10.1016/j.jtemb.2018.12.007 (2019).

48. Mireku, M. O. et al. Prenatal iron deficiency, neonatal ferritin, and infant cognitive function. Pediatrics https://doi.org/10.1542/ peds.2016-1319 (2016).

49. Bodnar, L. M., Siega-Riz, A. M. \& Cogswell, M. E. High prepregnancy BMI increases the risk of postpartum anemia. Obes. Res. 12, 941-948. https://doi.org/10.1038/oby.2004.115 (2004).

50. Bener, A., Al-Hamaq, A. O. \& Saleh, N. M. Association between vitamin D insufficiency and adverse pregnancy outcome: Global comparisons. Int. J. Womens Health 5, 523-531. https://doi.org/10.2147/ijwh.S51403 (2013).

51. Gomes da Costa, A., Vargas, S., Clode, N. \& Graça, L. M. Prevalence and risk factors for iron deficiency anemia and iron depletion during pregnancy: A prospective study. Acta Med. Port. 29, 514-518. https://doi.org/10.20344/amp.6808 (2016).

52. Figueiredo, A. C. C. et al. Association between vitamin D status during pregnancy and total gestational weight gain and postpartum weight retention: A prospective cohort. Eur. J. Clin. Nutr. 74, 126-134. https://doi.org/10.1038/s41430-019-0465-2 (2020).

53. Nobles, C. J., Markenson, G. \& Chasan-Taber, L. Early pregnancy vitamin D status and risk for adverse maternal and infant outcomes in a bi-ethnic cohort: The Behaviors Affecting Baby and You (B.A.B.Y.) Study. Br. J. Nutr. 114, 2116-2128. https://doi.org/ $10.1017 / \mathrm{s} 0007114515003980$ (2015).

54. Yun, C. et al. Vitamin D deficiency prevalence and risk factors among pregnant Chinese women. Public Health Nutr. 20, 1746-1754. https://doi.org/10.1017/s1368980015002980 (2017).

55. Wang, H. Y. et al. Correlation of serum vitamin D, adipose tissue vitamin D receptor, and peroxisome proliferator-activated receptor $\gamma$ in women with gestational diabetes mellitus. Chin. Med. J. (Engl.) 132, 2612-2620. https://doi.org/10.1097/cm9.0000000000 000480 (2019).

56. Chun, S. K., Shin, S., Kim, M. Y., Joung, H. \& Chung, J. Effects of maternal genetic polymorphisms in vitamin D-binding protein and serum 25-hydroxyvitamin D concentration on infant birth weight. Nutrition 35, 36-42. https://doi.org/10.1016/j.nut.2016. 10.006 (2017).

57. Tian, Y. et al. Maternal serum 25-hydroxyvitamin D concentrations during pregnancy and infant birthweight for gestational age: A three-cohort study. Paediatr. Perinat. Epidemiol. 30, 124-133. https://doi.org/10.1111/ppe.12262 (2016).

58. Thorp, J. M. et al. Vitamin D status and recurrent preterm birth: A nested case-control study in high-risk women. BJOG 119, 1617-1623. https://doi.org/10.1111/j.1471-0528.2012.03495.x (2012).

59. McAree, T. et al. Vitamin D deficiency in pregnancy-Still a public health issue. Matern. Child Nutr. 9, 23-30. https://doi.org/10. $1111 / \mathrm{mcn} .12014(2013)$.

60. Sen, S., Penfield-Cyr, A., Hollis, B. W. \& Wagner, C. L. Maternal obesity, 25-hydroxy vitamin d concentration, and bone density in breastfeeding dyads. J. Pediatr. 187, 147-152.e141. https://doi.org/10.1016/j.jpeds.2017.04.024 (2017).

61. Zhao, X. et al. Maternal vitamin D status in the late second trimester and the risk of severe preeclampsia in Southeastern China. Nutrients https://doi.org/10.3390/nu9020138 (2017).

62. Rodriguez, A. et al. Vitamin D status in pregnancy and determinants in a Southern European Cohort Study. Paediatr. Perinat. Epidemiol. 30, 217-228. https://doi.org/10.1111/ppe.12281 (2016).

63. Woon, F. C. et al. Vitamin D deficiency during pregnancy and its associated factors among third trimester Malaysian pregnant women. PLoS ONE 14, e0216439. https://doi.org/10.1371/journal.pone.0216439 (2019).

64. Davies-Tuck, M. et al. Vitamin D testing in pregnancy: Does one size fit all?. Aust. N. Z. J. Obstet. Gynaecol. 55, 149-155. https:// doi.org/10.1111/ajo.12278 (2015).

65. Thiele, D. K., Erickson, E. N. \& Snowden, J. M. High prevalence of maternal serum 25 -hydroxyvitamin D deficiency is not associated with poor birth outcomes among healthy white women in the Pacific Northwest. J. Obstetr. Gynecol. Neonatal Nursing JOGNN 48, 163-175. https://doi.org/10.1016/j.jogn.2019.01.001 (2019).

66. Leffelaar, E. R., Vrijkotte, T. G. \& van Eijsden, M. Maternal early pregnancy vitamin D status in relation to fetal and neonatal growth: Results of the multi-ethnic Amsterdam Born Children and their Development cohort. Br. J. Nutr. 104, 108-117. https:// doi.org/10.1017/s000711451000022x (2010).

67. Choi, R. et al. High prevalence of vitamin D deficiency in pregnant Korean women: The first trimester and the winter season as risk factors for vitamin D deficiency. Nutrients 7, 3427-3448. https://doi.org/10.3390/nu7053427 (2015).

68. Morales, E. et al. Deficit of vitamin D in pregnancy and growth and overweight in the offspring. Int. J. Obes. 2005(39), 61-68. https://doi.org/10.1038/ijo.2014.165 (2015).

69. Pereira-Santos, M., Queiroz Carvalho, G., David Couto, R., Barbosa Dos Santos, D. \& Marlucia Oliveira, A. Vitamin D deficiency and associated factors among pregnant women of a Sunny City in Northeast of Brazil. Clin. Nutr. ESPEN 23, 240-244. https://doi. org/10.1016/j.clnesp.2017.09.007 (2018). 
70. Merewood, A. et al. Widespread vitamin D deficiency in urban Massachusetts newborns and their mothers. Pediatrics 125, 640-647. https://doi.org/10.1542/peds.2009-2158 (2010).

71. Karlsson, T. et al. Lower vitamin D status in obese compared with normal-weight women despite higher vitamin D intake in early pregnancy. Clin. Nutr. 34, 892-898. https://doi.org/10.1016/j.clnu.2014.09.012 (2015).

72. Burris, H. H. et al. Vitamin D status and hypertensive disorders in pregnancy. Ann. Epidemiol. 24, 399-403.e391. https://doi.org/ 10.1016/j.annepidem.2014.02.001 (2014).

73. Huang, J. Y. et al. Association of serum vitamin D with symptoms of depression and anxiety in early pregnancy. J. Womens Health 2002(23), 588-595. https://doi.org/10.1089/jwh.2013.4598 (2014).

74. Fernández-Alonso, A. M. et al. First trimester serum levels of 25 -hydroxyvitamin D, free $\beta$-human chorionic gonadotropin, and pregnancy-associated plasma protein A in Spanish women. Gynecol. Endocrinol. 27, 1061-1064. https://doi.org/10.3109/09513 590.2011 .569799 (2011).

75. Francis, E. C. et al. Longitudinal maternal vitamin D status during pregnancy is associated with neonatal anthropometric measures. Nutrients https://doi.org/10.3390/nu10111631 (2018)

76. Johns, L. E. et al. Urinary BPA and phthalate metabolite concentrations and plasma vitamin D levels in pregnant women: A repeated measures analysis. Environ. Health Perspect. 125, 087026. https://doi.org/10.1289/ehp1178 (2017).

77. Luque-Fernandez, M. A. et al. Seasonal variation of 25-hydroxyvitamin D among non-Hispanic black and white pregnant women from three US pregnancy cohorts. Paediatr. Perinat. Epidemiol. 28, 166-176. https://doi.org/10.1111/ppe.12103 (2014).

78. Pérez-López, F. R. et al. First trimester serum 25-hydroxyvitamin D status and factors related to lower levels in gravids living in the Spanish Mediterranean coast. Reproduct. Sci. (Thousand Oaks, Calif.) 18, 730-736. https://doi.org/10.1177/1933719110396720 (2011).

79. Woolcott, C. G. et al. Determinants of vitamin D status in pregnant women and neonates. Can. J. Public Health Revue canadienne de sante publique 107, e410-e416. https://doi.org/10.17269/cjph.107.5629 (2016).

80. Jani, R., Knight-Agarwal, C. R., Bloom, M. \& Takito, M. Y. The association between pre-pregnancy body mass index, perinatal depression and maternal vitamin D status: Findings from an Australian Cohort Study. Int. J. Women's Health 12, 213-219. https:// doi.org/10.2147/ijwh.S239267 (2020).

81. Daraki, V. et al. Low maternal vitamin D status in pregnancy increases the risk of childhood obesity. Pediatr. Obes. 13, 467-475. https://doi.org/10.1111/ijpo.12267 (2018).

82. Figueiredo, A. C. C. et al. Changes in plasma concentrations of 25 -hydroxyvitamin D and 1,25-dihydroxyvitamin D during pregnancy: A Brazilian cohort. Eur. J. Nutr. 57, 1059-1072. https://doi.org/10.1007/s00394-017-1389-z (2018).

83. Tomedi, L. E. et al. Pre-pregnancy obesity and maternal nutritional biomarker status during pregnancy: A factor analysis. Public Health Nutr. 16, 1414-1418. https://doi.org/10.1017/s1368980013000736 (2013).

84. Pereira-Santos, M., Carvalho, G. Q., Dos Santos, D. B. \& Oliveira, A. M. Influence of vitamin D serum concentration, prenatal care and social determinants on birth weight: A northeastern Brazilian cohort study. Br. J. Nutr. 122, 284-292. https://doi.org/10. $1017 / \mathrm{s} 0007114519001004(2019)$

85. Kim, H. et al. Relationship between body-mass index and serum folate concentrations in pregnant women. Eur. J. Clin. Nutr. 66, 136-138. https://doi.org/10.1038/ejcn.2011.160 (2012).

86. Carmichael, S. L. et al. Elevated body mass index and decreased diet quality among women and risk of birth defects in their offspring. Birth Defects Res. Part A Clin. Mol. Teratol. 106, 164-171. https://doi.org/10.1002/bdra.23471 (2016).

87. Kroot, J. J., Tjalsma, H., Fleming, R. E. \& Swinkels, D. W. Hepcidin in human iron disorders: diagnostic implications. Clin. Chem. 57, 1650-1669. https://doi.org/10.1373/clinchem.2009.140053 (2011).

88. Nikonorov, A. A., Skalnaya, M. G., Tinkov, A. A. \& Skalny, A. V. Mutual interaction between iron homeostasis and obesity pathogenesis. J. Trace Elements Med. Biol. Organ Soc. Miner. Trace Elements (GMS) 30, 207-214. https://doi.org/10.1016/j.jtemb.2014. 05.005 (2015).

89. Krause, A. et al. LEAP-1, a novel highly disulfide-bonded human peptide, exhibits antimicrobial activity. FEBS Lett. 480, 147-150. https://doi.org/10.1016/s0014-5793(00)01920-7 (2000).

90. Adaikalakoteswari, A. et al. Vitamin B12 deficiency is associated with adverse lipid profile in Europeans and Indians with type 2 diabetes. Cardiovasc. Diabetol. 13, 129. https://doi.org/10.1186/s12933-014-0129-4 (2014).

91. Karatela, R. A. \& Sainani, G. S. Plasma homocysteine in obese, overweight and normal weight hypertensives and normotensives. Indian Heart J. 61, 156-159 (2009).

92. Guven, A., Inanc, F., Kilinc, M. \& Ekerbicer, H. Plasma homocysteine and lipoprotein (a) levels in Turkish patients with metabolic syndrome. Heart Vessels 20, 290-295. https://doi.org/10.1007/s00380-004-0822-4 (2005).

93. Gernand, A. D. et al. Maternal nutritional status in early pregnancy is associated with body water and plasma volume changes in a pregnancy cohort in rural Bangladesh. J. Nutr. 142, 1109-1115. https://doi.org/10.3945/jn.111.155978 (2012).

94. Aguree, S. \& Gernand, A. D. Plasma volume expansion across healthy pregnancy: A systematic review and meta-analysis of longitudinal studies. BMC Pregnancy Childbirth 19, 508. https://doi.org/10.1186/s12884-019-2619-6 (2019).

95. Moher, D., Liberati, A., Tetzlaff, J. \& Altman, D. G. Preferred reporting items for systematic reviews and meta-analyses: The PRISMA statement. BMJ (Clin. Res. Ed.) 339, b2535. https://doi.org/10.1136/bmj.b2535 (2009).

96. Stang, A. Critical evaluation of the Newcastle-Ottawa scale for the assessment of the quality of nonrandomized studies in metaanalyses. Eur. J. Epidemiol. 25, 603-605. https://doi.org/10.1007/s10654-010-9491-z (2010).

97. Sabbagh, H. J. et al. Passive smoking in the etiology of non-syndromic orofacial clefts: A systematic review and meta-analysis. PLoS ONE 10, e0116963. https://doi.org/10.1371/journal.pone.0116963 (2015).

98. Scott-Pillai, R., Spence, D., Cardwell, C. R., Hunter, A. \& Holmes, V. A. The impact of body mass index on maternal and neonatal outcomes: A retrospective study in a UK obstetric population, 2004-2011. BJOG 120, 932-939. https://doi.org/10.1111/1471-0528. 12193 (2013).

99. Kell, D. B. \& Pretorius, E. Serum ferritin is an important inflammatory disease marker, as it is mainly a leakage product from damaged cells. Metallomics Integrated Biometal Sci. 6, 748-773. https://doi.org/10.1039/c3mt00347g (2014).

\section{Acknowledgements}

This work was supported by grants from the National Natural Science Foundation of China (82070807, 91749118, 81770775, 81730022), Natural Science Foundation of Hunan Province, China (2021JJ30976) and National key research and development program (2019YFA0801903, 2018YFC2000100).

\section{Author contributions}

J.Z. coordinated and planned the study. Y.Y. conceived the study, along with Z.C. and J.Z., and contributed to the study design, literature search, statistical analysis, and data synthesis of the outcomes. Y.Y. prepared the first draft of the manuscript with significant help from Z.C. and J.Z. All the authors critically revised the results to produce the final version. 


\section{Competing interests}

The authors declare no competing interests.

\section{Additional information}

Supplementary Information The online version contains supplementary material available at https://doi.org/ 10.1038/s41598-021-97635-3.

Correspondence and requests for materials should be addressed to J.Z.

Reprints and permissions information is available at www.nature.com/reprints.

Publisher's note Springer Nature remains neutral with regard to jurisdictional claims in published maps and institutional affiliations.

(c) (1) Open Access This article is licensed under a Creative Commons Attribution 4.0 International License, which permits use, sharing, adaptation, distribution and reproduction in any medium or format, as long as you give appropriate credit to the original author(s) and the source, provide a link to the Creative Commons licence, and indicate if changes were made. The images or other third party material in this article are included in the article's Creative Commons licence, unless indicated otherwise in a credit line to the material. If material is not included in the article's Creative Commons licence and your intended use is not permitted by statutory regulation or exceeds the permitted use, you will need to obtain permission directly from the copyright holder. To view a copy of this licence, visit http://creativecommons.org/licenses/by/4.0/.

(C) The Author(s) 2021 